The flexibility of Industrial Additive Manufacturing Systems

\begin{tabular}{|r|l|}
\hline Journal: & International Journal of Operations and Production Management \\
\hline Manuscript ID & IJOPM-04-2016-0200.R4 \\
\hline Manuscript Type: & Research Paper \\
\hline Keywords: & $\begin{array}{l}\text { Advanced Manufacturing Technology (AMT), Flexibility, Management of } \\
\text { technology, Manufacturing flexibility, additive manufacturing }\end{array}$ \\
\hline
\end{tabular}




\section{The flexibility of Industrial Additive Manufacturing Systems}

\section{Purpose}

Flexibility is a fundamental performance objective for manufacturing operations, allowing them to respond to changing requirements in uncertain and competitive global markets. Additive Manufacturing machines are often described as 'flexible', but there is no detailed understanding of such flexibility in an Operations Management context. This study examines flexibility from a manufacturing systems perspective, demonstrating the different competencies that can be achieved and the factors that can inhibit these in commercial practice.

\section{Design / Methodology / Approach}

This study extends existing flexibility theory in the context of an Industrial Additive Manufacturing System through an investigation of twelve case studies, covering a range of sectors, product volumes, and technologies. Drawing upon multiple sources, this research takes a manufacturing systems perspective that recognizes the multitude of different resources that, together with individual Industrial Additive Manufacturing machines, contribute to the satisfaction of demand.

\section{Findings}

The results show that the manufacturing system can achieve seven distinct internal flexibility competencies. This ability was shown to enable six out of seven external flexibility capabilities identified in the literature. Through a categorical assessment the extent to which each competency can be achieved is identified, supported by a detailed explanation of the enablers and inhibitors of flexibility for Industrial Additive Manufacturing Systems.

\section{Originality / Value}

Additive Manufacturing is widely expected to make an important contribution to future manufacturing, yet relevant management research is scant and the flexibility term is often ambiguously used. This research contributes a first detailed examination of flexibility for Industrial Additive Manufacturing Systems. 
The flexibility of Industrial Additive Manufacturing Systems 


\section{Introduction}

A long established competitive priority for manufacturing is the ability to achieve flexibility (Leong et al. 1990), which may also influence the performance of other competitive objectives (Gerwin 1987). Flexibility often constitutes a key tenet of an organization's competitive strategy (Cousens et al. 2009), and it can be leveraged either in response to changing circumstances or as a proactive measure in anticipation of future change (de Toni and Tonchia 1998). As a result, in the continually changing and highly uncertain business environment that modern manufacturers operate in, flexibility is often viewed as a means to achieve competitive advantage over rivals in a global market (Ghadge et al. 2012).

Contemporary studies frequently identify the technologies of "Additive Manufacturing" as facilitating the achievement of flexibility within manufacturing operations. Capable of producing complex physical products directly from 3D computer models without the need for tooling, these technologies have been identified as "game changing" (Brennan et al. 2015, pp. 1263; MacCarthy et al. pp. 1697), and potentially radically affecting operations practice (D'Aveni 2015). Once limited to the production of prototype parts, Additive Manufacturing is today employed in a wide range of commercial applications including the production of end-user products (Eyers and Dotchev 2010), and increasingly forms an important contribution to national manufacturing strategies (e.g. European Commission 2014; Foresight 2013; Obama 2013), highlighting its potential role as a future enabler of competitive manufacturing.

Existing literature has already described Additive Manufacturing as offering flexibility (e.g. Onuh and Hon 2001), with some terming it "a flexible factory in a box" (Alpern 2010, pp. 47). There is, however, little consistency between studies regarding the meaning of "flexibility" in this context. Whilst decades of research have provided a plethora of types to evaluate flexibility, to-date there has been no explicit focus on what types of flexibility Additive Manufacturing affords, nor how they are achieved. This is an important omission, since such lack of specificity is well-established as an inhibitor to the achievement of flexibility in manufacturing (Jain et al. 2013), and can lead to costly mistakes (Hill and Chambers 1991).

Understanding manufacturing flexibility requires an appreciation of both the internal flexibility competencies and the external flexibility capabilities, together with an awareness of the relationship between these (Zhang et al. 2003). The predominant focus to-date has been on the external capabilities of Additive Manufacturing, with little assessment of the internal competencies to achieve this. Moreover, most evaluations have focused on the technological contribution of individual Additive Manufacturing machines, yet traditionally the multifarious resources of manufacturing 
systems combine to provide flexibility, rather than just one single manufacturing technology (Slack 2005).

In response to this research gap, the aim of this paper is to advance understanding on the flexibility of Industrial Additive Manufacturing Systems (IAMS), with emphasis on the competencies and capabilities that may either support or inhibit flexibility. Mindful that fulfilment of demand in Additive Manufacturing is achieved through a complex combination of resources (of which Additive Manufacturing machines are just one contributor), this paper takes a systems theory perspective in its assessment of flexibility for the Industrial Additive Manufacturing System. Such a systems viewpoint has long been advocated in manufacturing research (Parnaby 1979), but has not been a perspective by which Additive Manufacturing has been evaluated. We bound the system in a traditional manner, with consideration of flexibility therefore including the related machine, preproduction and postproduction activities, as well as labour and information components. These combine to create an Industrial Additive Manufacturing System that receives materials from suppliers and satisfies customer demand for manufactured goods, and hence our system boundary also defines the scope of our data collection and analysis given in Section 3. The structure of this paper is shown in Figure 1.

\begin{tabular}{|c|c|c|c|c|c|c|}
\hline Activity & $\begin{array}{l}\text { Identification of study } \\
\text { context \& research aim }\end{array}$ & $\begin{array}{l}\text { Additive Manufacturing } \\
\text { flexibility revicw \& } \\
\text { initial theoretical } \\
\text { development }\end{array}$ & $\begin{array}{l}\text { Operationalization of } \\
\text { flexibility typology } \\
\text { method }\end{array}$ & $\begin{array}{l}\text { Intcrnal flexibility } \\
\text { competences assessment }\end{array}$ & $\begin{array}{l}\text { Extcrnal flexibility } \\
\text { capabilities assessment }\end{array}$ & $\begin{array}{l}\text { Contextualizing lindings } \\
\text { to existing body of } \\
\text { knowledge }\end{array}$ \\
\hline $\begin{array}{l}\text { Nature of } \\
\text { research }\end{array}$ & Observational & Theoretical & Theoretical \& empirical & Empirical & Empirical & Empirical \& theoretical \\
\hline Outeomes & $\begin{array}{l}\text { Initial insights from } \\
\text { theory \& practical } \\
\text { observations identified }\end{array}$ & $\begin{array}{c}\text { Research gaps } \\
\text { confirmed. Research } \\
\text { qucstions \& flexibility } \\
\text { typology formulated }\end{array}$ & $\begin{array}{l}\text { Flexibility assessment } \\
\text { schema \& procedure } \\
\text { employed for twolve } \\
\text { ease studies }\end{array}$ & $\begin{array}{l}\text { Detailed assessment of } \\
\text { intemal flexibility } \\
\text { competences for twelve } \\
\text { case studies }\end{array}$ & $\begin{array}{l}\text { Identification of external } \\
\text { capability enablement } \\
\text { and dcrivation of } \\
\text { emergent capabilities }\end{array}$ & $\begin{array}{l}\text { Rescarch qucstions } \\
\text { answered, limitations } \\
\text { explaincd, and futuro } \\
\text { research suggested }\end{array}$ \\
\hline $\begin{array}{c}\text { Modus } \\
\text { operandi }\end{array}$ & $\begin{array}{l}\text { Literaturc-based with } \\
\text { reference to practice }\end{array}$ & Literature-based & $\begin{array}{l}\text { Qualitative: Imtervicws, } \\
\text { observations, company } \\
\text { documents }\end{array}$ & $\begin{array}{c}\text { Tcam-bascd } \\
\text { interpretation \& analysis } \\
\text { of data }\end{array}$ & $\begin{array}{c}\text { Team-based } \\
\text { interpretation \& analysis } \\
\text { of data }\end{array}$ & Reflective appraisal \\
\hline Focus in & Section I & Section 2 & Section 3 & Section 4 & Section 5 & Section 6 \\
\hline
\end{tabular}

Figure 1: Paper structure

\section{Literature Review}

\subsection{Defining flexibility}

Despite a long academic pedigree, consensus as to what flexibility is remains contested, and numerous reviews (e.g. Beach et al. 2000; Bernardes and Hanna 2009; de Toni and Tonchia 1998; Jain et al. 2013; Sethi and Sethi 1990; Stevenson and Spring 2007) have all explored its definition. Several authors have offered explanations for the lack of consensus, such as Sethi and Sethi (1990, pp. 289), who identified flexibility to be "a complex, multidimensional, and hard-to-capture concept", whilst Oke (2005, pp. 947) further posited that "because flexibility cuts across the entire organization and academic literature, it has proved difficult to adequately conceptualize and understand". From an operational perspective, Upton (1994) has noted that such ambiguity has hampered effective 
management. There are, however, four main themes in the literature that can support a definition of flexibility suitable for this study: flexibility to enable change, perspectives on flexibility, flexibility types, and flexibility dimensions.

Theme 1: Flexibility to enable change

Flexibility allows a manufacturing system to change its state (Das 2001) in response to changing requirements or circumstances (Gerwin 1987; Sethi and Sethi 1990). Change may be needed due to the operations of the manufacturing system, or from factors outside of it: for example, Brill and Mandelbaum (1989) suggest change requirements could arise from production changes in process efficiencies or capacities, or from changes in customer demand or pricing. Notably this change is not the 'changeability' of the system, since flexibility concerns the way in which a system moves to-andfrom states, whereas change from a changeability perspective is permanent (Oke 2005). Change cannot always be anticipated, and so flexibility is often linked with uncertainty in manufacturing (Newman et al. 1993). Uncertainties arise from many sources, so the ability of a system to achieve a multitude of different types of flexibility is advantageous (de Neufville and Scholtes 2011).

Theme 2: Perspectives on flexibility

The perspective by which flexibility is evaluated concerns what the system can do (internal perspective), and what the customer perceives it to do (external perspective) (Upton 1994). Whilst perspectives are often confused in literature (Oke 2005), understanding whether one is thinking about flexibility as a production operative, a manufacturing manager, or a customer is essential. Such perspectives underpin Zhang et al. (2003) who link internal flexibility to the competencies of the manufacturing system, and external flexibility to the capabilities that are achieved as a result.

Theme 3: Flexibility types

Flexibility is a multifaceted concept, with many different types of flexibility identified in the literature. Flexibility types provide a name and descriptive definition of that type, whereas measures provide a means to evaluate a flexibility type under given conditions (Shewchuk and Moodie 1998). A multitude of flexibility types have been proposed in research, though as Petkova and van Wezel observe (2006, pp. 1), "although many kinds of flexibility have been specified, production literature tends to repeat and adjust the existing types". Furthermore, interpretations of flexibility type definitions often vary between studies; for example, Gupta and Goyal (1989) identified nine different definitions of the 'process flexibility' type used within twelve studies.

Despite the breadth of flexibility types and definitions, their overlaps and duplications, some clarity may be achieved by considering those types commonly used in contemporary work. It is apparent that the traction gained by early authors such as Gerwin (1982), Slack (1983), and Browne et al. (1984), 
together with the support of seminal review papers such as Sethi and Sethi (1990) has helped focus attention towards the early-defined fundamental flexibility types. When producing a classification of flexibility, Jain et al. (2013) utilized the types included in the three most-cited flexibility review papers (namely Browne et al. (1984), Sethi and Sethi (1990), and Koste and Malhotra (1999)), yielding 12 flexibility types. However, even this technique struggles to achieve consensus, with some flexibility types (e.g. 'Market Flexibility' or 'Labour Flexibility') appearing in only one of the three articles, and much variation in definitions offered for the same flexibility types. Building on Jain et al. (2013), excluding types that do not enjoy inclusion in multiple reviews, and focusing on those that consider flexibility from the internal perspective (see Theme 2), we identify seven distinct internal flexibility types. Table 1 provides a summary of these from five highly cited and seminal reviews of flexibility in an Operations context, together with an overview of applications research for each type. 
Table 1: Internal Flexibility Types: Definitions and Contemporary Research Focus

\begin{tabular}{|c|c|c|c|}
\hline $\begin{array}{c}\text { Internal } \\
\text { Flexibility Type } \\
\end{array}$ & $\begin{array}{c}\text { Review Paper } \\
\text { Authors }\end{array}$ & Flexibility Definition & $\begin{array}{c}\text { Examples of } \\
\text { Applications Research }\end{array}$ \\
\hline \multirow{5}{*}{$\begin{array}{l}\text { Equipment } \\
\text { Flexibility } \\
\text { sometimes } \\
\text { termed 'machine } \\
\text { flexibility' }\end{array}$} & Browne et al. (1984) & The ease of making the changes required to a given set of part types. & \multirow{5}{*}{$\begin{array}{l}\text { Relation to labour } \\
\text { (Francas et al. 2011) } \\
\text { Effect on system } \\
\text { performance (Mohamed } \\
\text { et al. 2001; Nandkeolyar } \\
\text { and Christy 1992) }\end{array}$} \\
\hline & $\begin{array}{l}\text { Koste and Malhotra } \\
\text { (1999) }\end{array}$ & $\begin{array}{l}\text { The number and heterogeneity variety of operations a machine can execute without incurring high transition } \\
\text { penalties or large changes in performance outcomes. }\end{array}$ & \\
\hline & $\begin{array}{l}\text { Sethi and Sethi } \\
(1990)\end{array}$ & $\begin{array}{l}\text { The various types of operations that the machine can perform without requiring a prohibitive effort in } \\
\text { switching from one operation to another. }\end{array}$ & \\
\hline & $\begin{array}{l}\text { Narishman and Das } \\
\text { (1999) }\end{array}$ & The ability of a machine to switch among different operations without prohibitive effort. & \\
\hline & $\begin{array}{l}\text { Vokurka, R. J. and } \\
\text { O'Leary-Kelly (2000) }\end{array}$ & The range of operations that a piece of equipment can perform without incurring a major setup. & \\
\hline \multirow{5}{*}{$\begin{array}{l}\text { Process } \\
\text { flexibility }\end{array}$} & Browne et al. (1984) & The ability to produce a given set of part types, each possible using different materials, in several ways. & \multirow{5}{*}{$\begin{array}{l}\text { Ability to support } \\
\text { product variety } \\
\text { (Matthews et al. 2006) } \\
\text { Relation to machine } \\
\text { flexibility (Boyer and } \\
\text { Leong 1996) }\end{array}$} \\
\hline & $\begin{array}{l}\text { Koste and Malhotra } \\
(1999)^{*}\end{array}$ & $\begin{array}{l}\text { The number and variety heterogeneity of products that can be produced without incurring high transition } \\
\text { penalties or large changes in performance outcomes. }\end{array}$ & \\
\hline & $\begin{array}{l}\text { Sethi and Sethi } \\
(1990)\end{array}$ & The set of part types that the system can produce without major setups. & \\
\hline & $\begin{array}{l}\text { Narishman and Das } \\
(1999)^{*}\end{array}$ & The ability of the manufacturing system to switch between different products in the product mix. & \\
\hline & $\begin{array}{l}\text { Vokurka, R. J. and } \\
\text { O'Leary-Kelly (2000) }\end{array}$ & The number of different parts produced without incurring a major setup. & \\
\hline \multirow{5}{*}{$\begin{array}{l}\text { Operation } \\
\text { flexibility } \\
\text { sometimes } \\
\text { termed 'sequence } \\
\text { flexibility' }\end{array}$} & Browne et al. (1984) & The ability to interchange the ordering of several operations for each part type. & \multirow{5}{*}{$\begin{array}{l}\text { Modelling potential } \\
\text { sequences and their } \\
\text { effects (Benjaafar and } \\
\text { Ramakrishnan 1996; } \\
\text { Hutchinson and } \\
\text { Pflughoeft 1994) }\end{array}$} \\
\hline & $\begin{array}{l}\text { Koste and Malhotra } \\
(1999)\end{array}$ & $\begin{array}{l}\text { The number of products that have alternate sequencing plans and the heterogeneity variety of the plans used } \\
\text { without incurring high transition penalties or large changes in performance outcomes. }\end{array}$ & \\
\hline & $\begin{array}{l}\text { Sethi and Sethi } \\
(1990)\end{array}$ & The ability to produce a part in different ways. & \\
\hline & $\begin{array}{l}\text { Narishman and Das } \\
(1999)\end{array}$ & Not discussed. & \\
\hline & \begin{tabular}{|l|} 
Vokurka, R. J. and \\
O'Leary-Kelly (2000)
\end{tabular} & The number of alternative processes or ways in which a part can be produced within the system. & \\
\hline \multirow{4}{*}{$\begin{array}{l}\text { Capacity } \\
\text { flexibility } \\
\text { sometimes } \\
\text { termed } \\
\text { 'expansion } \\
\text { flexibility' }\end{array}$} & Browne et al. (1984) & The capability of building a system, and expanding it as needed, easily and modularly. & \multirow{4}{*}{$\begin{array}{l}\text { Managing capacity } \\
\text { flexibility (Tanrisever et } \\
\text { al. 2012) } \\
\text { Balancing flexible and } \\
\text { dedicated capacity } \\
\text { (Gupta et al. 1992) }\end{array}$} \\
\hline & $\begin{array}{l}\text { Koste and Malhotra } \\
\text { (1999) }\end{array}$ & $\begin{array}{l}\text { The number and heterogeneity variety of expansions that can be accommodated without incurring high } \\
\text { transition penalties or large changes in performance outcomes. }\end{array}$ & \\
\hline & $\begin{array}{l}\text { Sethi and Sethi } \\
(1990)\end{array}$ & The ease with which the capacity and capability of a manufacturing system can be increased when needed. & \\
\hline & Narishman and Das & The ability to expand capacity without prohibitive effort. & \\
\hline
\end{tabular}




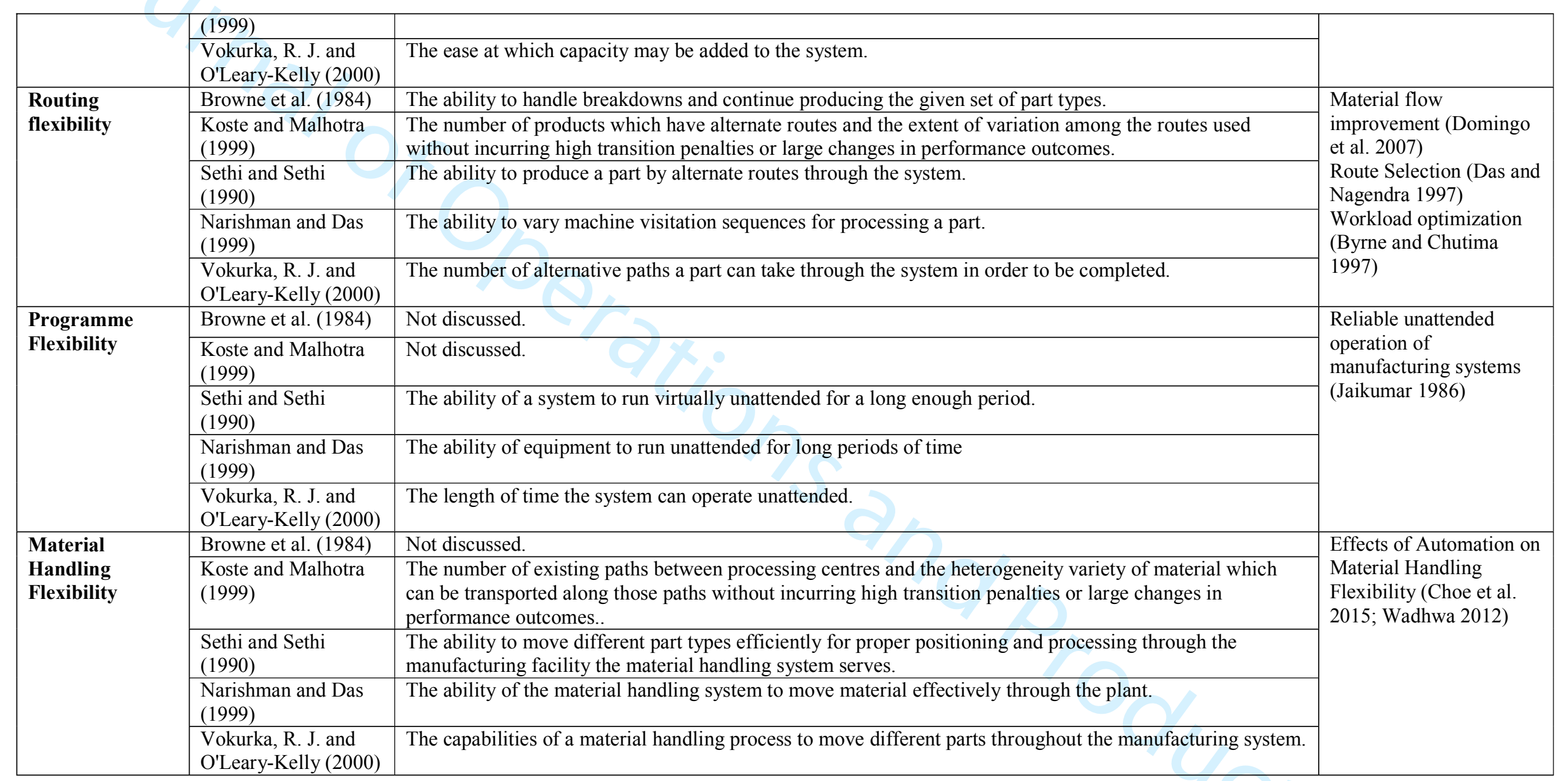


Theme 4: Flexibility dimensions

Each flexibility type has two dimensions: range and response (Slack 1987). The range dimension concerns the multitude of states or behaviours a system may enter whilst still maintaining its flexibility. For example, in mix flexibility the range dimension concerns the number of different products that a system can produce (Bateman 1999). In principle, one system capable of more states relative to a second system may be considered more flexible. However, if making the change is difficult or incurs a penalty this must be regarded as an inhibitor of flexibility. This is recognized in the response dimension, which concerns the ease a system may move between states in terms of the well-established flexibility penalties of time, effort, cost, or performance (Upton 1994).

\subsection{The flexibility of Industrial Additive Manufacturing Systems}

Whilst Additive Manufacturing is identified by many authors as "flexible" or offering "flexibility", our literature review found little consistency in the definitions used, and scant explanation as to how or why flexibility arises. We performed a detailed review of English language articles referring to Additive Manufacturing (or the related terms of Rapid Prototyping, Rapid Tooling, Rapid Manufacturing, and 3D Printing), and all variations on the flexibility term (using a wildcard on 'flexib*'). We found very little precision in the use of the term flexibility, with the words 'flexible' and 'flexibility' typically used in a pleonastic manner, devoid of detail and failing to add to our understanding of flexibility for Additive Manufacturing. Importantly, we identified no strong linkage between such mentions of flexibility for Additive Manufacturing and the detailed understanding of flexibility that exists within Operations Management research, confirming the research gap for the current study.

Although little relevant literature was found on Additive Manufacturing flexibility from an Operations Management perspective, it was possible to identify some studies that could inform the development of this research. Using the competency/capability delimitation of Zhang et al. (2003), it is identified that most Additive Manufacturing studies adopt an external capability perspective on flexibility, with very little detailed focus on the internal flexibility competencies that enable this. A detailed review of the literature identified seven external capabilities of Additive Manufacturing as follows:

\subsubsection{Flexibility to manufacture 'on-demand'}

Several authors identify flexibility to arise from an ability to manufacture products "on-demand" i.e. in response to customer orders, without some of the penalties associated in conventional manufacturing. This has been linked to the achievement of low volume production through short production runs (Chhabra and Singh 2011; Ford et al. 2014), and the ability to quickly achieve 
production (Reinke 2007; Grzesiak et al. (2011)). Examples such as Pérès and Noyes (2006) identify that such flexibility can be particularly useful for applications such as spare parts, allowing companies to produce these as required rather than hold inventories of stock in anticipation of future demand.

\subsubsection{Flexibility in design practice}

One of the frequently-cited advantages of Additive Manufacturing is the design freedoms that arise by the elimination of many constraints found in conventional manufacturing. Several authors suggest this leads to an external flexibility capability in terms of design, though there are multiple variations on this idea. Some studies have linked flexibility to the range of different designs that can be produced (Bak 2003; Karevan et al. 2013), which in turn would yield improvements in the range of products offered. Other authors have considered the nature of the products themselves, considering flexibility as an ability to achieve complexity in designs (Bourell et al. 2011; Brenne et al. 2013). By extension, Additive Manufacturing has been identified as promoting flexibility by allowing customization of existing product designs (Melchels et al. 2012), which Heralić et al. (2012) note can be made late in the design cycle.

\subsubsection{Flexibility to produce a wide range of parts}

Extending from the ability to design a range of parts is the external capability to physically produce these using Additive Manufacturing machines. Rosen (2004, pp. 43) identified that "[Additive Manufacturing] systems will be very flexible in that they will be capable of fabricating a wide variety of parts, and, potentially, products or modules". These could be wholly new products, be customizations of existing designs (Craeghs et al. 2010), or have different physical or mechanical properties (Kumar and Choudhury 2002; Wong et al. 2007). Akin to process flexibility, Prabhu et al. (2005) link process parameter variation with flexibility as it can control the way parts are produced.

\subsubsection{Flexibility to fabricate a wide range of complex geometries}

Several authors consider flexibility as enabling the production of a wide range of complex shaped parts (e.g. Jin et al. 2013; Schmidt et al. 2007). Zhang et al. (2013) provide more specificity, suggesting that flexibility is the ease of achieving complex shapes relative to conventional approaches, and Thijs et al. (2010) suggest it concerns an ability for simultaneous manufacture of complex-geometry parts. Several authors identify this flexibility to be technology-specific: Brandl et al. (2012) found technologies using a powder-bed offer the highest capability for geometric flexibility and accuracy, whilst Canellidis et al. (2013) emphasized the importance of optimizing geometric flexibility in resin-based processes for cost-effective manufacturing. 


\subsubsection{Flexibility to use many different materials}

Flexibility may also concern the range of different materials that an individual machine may process (e.g. Furumoto et al. 2012; Levy et al. 2003). No discussion was found to quantify this range, however some processes were identified as offering far more opportunity than others, either in terms of the materials used or their processing technique (Dadbakhsh et al. 2012; Glardon et al. 2001).

\subsubsection{Flexibility to fabricate products without tooling}

Additive Manufacturing does not require tooling, which several authors suggest make it flexible. For example, Chimento et al. (2011, pp. 387) state Additive Manufacturing "increase manufacturing flexibility by eliminating the need for part-specific tools". This is echoed by Xiong et al. (2013) and Bak (2003), who found the elimination of tooling also reduces production costs, and by Overmeyer et al. (2011) and Pérès and Noyes (2006) who identify flexiblity to arise by enabling fabrication directly from 3D design models without the burden of tooling.

\subsubsection{Flexibility to exploit process variables for efficient production}

Many studies suggest Additive Manufacturing technologies offer flexibility in their processes, though neither the nature of this process flexibility nor its achievement is clearly defined. Several authors (Jiang et al. 2013; Pfleging et al. 2007) advocate that Additive Manufacturing technologies offer high levels of process flexibility, but the measurement of this capability is unspecified. Process flexibility is found as being "good" (Ma et al. 2013, pp. 209), can lead to efficiencies in production (Wilden and Fischer, 2007), and for specific applications, is an advantageous capability (Kuo and Su 2013). Some authors are more precise in their treatment of the term; for example, West et al. (2001) ascertained that for some specific machines, process flexibility concerns the number of different process variables that can be handled, and leads directly to both accuracy and efficiency in part fabrication. Flexibility in this sense therefore concerns the various parameters that an operator can choose in the preparation of the machine for production.

In conclusion, this section has provided a detailed review on the overall nature of flexibility, together with a focused exploration in the context of Additive Manufacturing that serves to underpin the remainder of the article. Whilst flexibility in general is a well-established and sophisticated concept, ambiguity and inconsistency besets its terminology and this section has provided clarification for terminologies used in this paper. For Additive Manufacturing, this review has shown there has been very little focus on internal flexibility competencies but has 
identified seven external flexibility capabilities from the published literature. Consequently, to address the previously stated aim of this research we pose two research questions:

Research Question 1: How can flexibility competencies and capabilities be empirically assessed for an Industrial Additive Manufacturing System?

Research Question 2: How is the flexibility of an Industrial Additive Manufacturing System influenced by different flexibility competencies and capabilities?

\section{Methodology}

\subsection{Case study research design}

Given the overall paucity of detailed knowledge identified in the literature review considering how flexibility arises in IAMS, this study employs case research as it enables empirical research of contemporary phenomena within real-life situations (Yin 2009), offering the opportunity to engage with informants at all levels of organizations in practitioner-relevant research (Voss et al. 2002). Existing studies have advocated a focus on individual products when determining strategies for manufacturing and supply chain management (Childerhouse et al. 2002; Fisher et al. 1997), and this was observed in practice with the focal companies. As a result, this study uses individual products as the Unit of Analysis for the case studies, which aids evaluation in terms of different manufacturing systems and different products. Theoretical sampling was employed as the research progressed, using diverse cases that varied widely from each other (Stuart et al. 2002), which helps to understand whether individual case findings are idiosyncrhatic or consistently replicated across cases (Eisenhardt and Graebner, 2007). Specifically, cases were chosen that varied in terms of the product, the application attributes (prototypes, tools, or end-use products), and the manufacturing attributes (volume and variety/customization). Twelve case studies were examined (Table 2) involving three well-established Industrial Additive Manufacturing companies (Table 3).

Twenty-two interviews of directors, managers, and technicians informed the research, enabling the achievement of different perspectives concerning the manufacturing system's operation. Additionally, the use of observation was important to understand the achievement of flexibility in practise, allowing a real-time understanding of events as they arose, rather than through postrationalized interviews. To better understand the focal operations, additional data was drawn from company documents, and four interviews conducted with customers. Throughout, a detailed understanding of the products offered was focus of this data collection, including the way in which these were produced, and the specific contributions and implications arising from manufacturing flexibility in Industrial Additive Manufacturing Systems. 
Additionally, 15 supplier interviews enabled improved understanding of the supply chain, particularly in terms of its flexibility. Whilst these do not link directly to specific cases, the data provided useful background information on how the companies worked with suppliers and customers, the need for flexibility, and how this was achieved. Voss et al. (2002) identified the potential to conduct research over a longer timeframe is beneficial, and this study was conducted over a six-year period. Whilst this was not intended as a longitudinal study to examine how flexibility attainment changed over time, such an extended period was very useful in developing relationships with the focal companies. This improved our confidence in the data reported by interviewees, and allowed the researchers to achieve a good understanding of the operations through multiple site visits. 
Table 2 Case summaries (Source: Authors)

\begin{tabular}{|c|c|c|c|c|c|c|c|}
\hline $\begin{array}{l}\text { Case } \\
\text { No. }\end{array}$ & Company & Product Description & Volume (annual) & $\begin{array}{c}\text { Variety/ } \\
\text { Customization }\end{array}$ & Design source & $\begin{array}{l}\text { Production } \\
\text { lead-time }\end{array}$ & Approach \\
\hline 1 & A & In-The-Ear (ITE) Hearing Aid & Tens of thousands & High & $\begin{array}{c}\text { Reverse } \\
\text { Engineered }\end{array}$ & 1 day & MTO \\
\hline 2 & $\mathrm{~B}$ & Model medieval ship & $\begin{array}{l}1 \text { (comprised of } \\
10 \text { batches of } \\
\text { components) }\end{array}$ & High & $\begin{array}{l}\text { Reverse } \\
\text { Engineered }\end{array}$ & 2 weeks / batch & MTO \\
\hline 3 & $\mathrm{~B}$ & Scale models of ancient stone monuments & 4 & High & $\begin{array}{c}\text { Reverse } \\
\text { Engineered }\end{array}$ & 2 weeks & MTO \\
\hline 4 & B & Architectural scale models of complex shaped buildings & 20 & High & Human Design & 1 week & MTO \\
\hline 5 & B & $\begin{array}{l}\text { Hydroform tool inserts to be used in the production of exhaust } \\
\text { systems }\end{array}$ & 1 & High & $\begin{array}{c}\text { Reverse } \\
\text { Engineered }\end{array}$ & 2 weeks & MTO \\
\hline 6 & B & Inspection fixture for prototype toothbrush & 1 & High & Human Design & 1 week & MTO \\
\hline 7 & B & Functional prototype of an exhaust sensor tool & 3 & High & Human Design & 1 week & MTO \\
\hline 8 & $\mathrm{C}$ & Customized surgical guide & Tens of thousands & High & $\begin{array}{c}\text { Reverse } \\
\text { Engineered }\end{array}$ & 3 weeks & MTO \\
\hline 9 & $\mathrm{C}$ & Customized lighting product designed by customer via website & Hundreds & Medium & $\begin{array}{l}\text { Catalogue } \\
\text { Design }\end{array}$ & $1-2$ weeks & MTO \\
\hline 10 & $\mathrm{C}$ & Standardized lighting product designed by professional designer & $\begin{array}{l}\text { Hundreds - } \\
\text { thousands }\end{array}$ & Low & $\begin{array}{c}\text { Online } \\
\text { Configurator }\end{array}$ & 2 weeks & MTS \\
\hline 11 & $\mathrm{C}$ & Hybrid fixture system customized for user application & $\begin{array}{l}\text { Hundreds - } \\
\text { thousands }\end{array}$ & Medium & $\begin{array}{c}\text { Reverse } \\
\text { Engineered }\end{array}$ & 3 days & MTO \\
\hline 12 & $\mathrm{C}$ & Designer furniture & 1 & High & Human Design & 1 week & MTO \\
\hline
\end{tabular}




\subsection{Flexibility typology and analysis schema}

Flexibility within a manufacturing system arises through the attainment of internal flexibility competencies (Zhang et al. 2003), and in this study the typology in Table 4 was established to achieve a manageable yet detailed flexibility assessment. Two factors motivated its development:

1. The identified internal flexibility types are well defined and understood in academic literature, and our definitions are derived from the previous summary in Table 1.

2. Data collection with manufacturers and some customers highlighted their awareness of flexibility for other manufacturing processes, and so it was desirable to use similar terminology in this assessment. 
Table 4: A typology of IAMS internal flexibility competencies

\begin{tabular}{|l|l|}
\hline \multicolumn{1}{|c|}{ Flexibility Type } & \multicolumn{1}{c|}{ Definition } \\
\hline Equipment flexibility & The ability of the equipment to change between different operations. \\
\hline Process flexibility & $\begin{array}{l}\text { The ability to produce parts in the same manufacturing system in } \\
\text { different ways. }\end{array}$ \\
\hline Operation flexibility & The ability to change the sequence in which production occurs. \\
\hline Capacity flexibility & The ability to increase or decrease production capacity. \\
\hline Routing flexibility & $\begin{array}{l}\text { The ability to change the route taken by parts through the production } \\
\text { process. }\end{array}$ \\
\hline Program flexibility & $\begin{array}{l}\text { The ability for equipment to operate unattended for extended time } \\
\text { periods. }\end{array}$ \\
\hline $\begin{array}{l}\text { Material Handling } \\
\text { Flexibility }\end{array}$ & \begin{tabular}{l} 
The ability for materials to move effectively though the plant. \\
\hline
\end{tabular} \\
\hline
\end{tabular}

The intention of this analysis was to identify the internal competencies of an IAMS that support or inhibit flexibility, rather than to attempt to quantify these; this study explores the qualitative how rather than the quantitative how much. Quantification requires the assignment of a value for given conditions of the manufacturing system, however as these change, flexibility becomes more difficult to assess and is thus very hard to quantify (Parnaby 1987). A particular problem is that flexibility can be a potential rather than realized attribute of a manufacturing system (Slack 1983), therefore quantifying what is possible, rather than what is observed poses many problems in the measurement of internal flexibility. This study therefore employs a classification based on the penalty arising from change, orientated around the response dimension of flexibility. Each flexibility type is categorized in terms one of three different response penalty rankings:

1. Class 1 flexibility: offering a flexibility type that enjoys a high degree of range flexibility yet does not incur a penalty of response.

2. Class 2 flexibility: offering high, or relatively high, range flexibility but with a small associated penalty in making this response.

3. Class 3 flexibility: offering a high, or relatively high degree of range flexibility but with a commensurate and tolerable response penalty that is acceptable based on the advantage gained. This is the lowest class recognizable as meriting a flexible definition; any lower capabilities are not deemed to adequately meet the characterisation of 'little' penalty offered by Upton (1994) in terms of cost, time, or the degradation of output.

Such use of categoric flexibility assessments is well established in qualitative research. For example, Naim et al. (2010) utilized "High-Medium-Low" assessments based on transport flexibility, an 
approach also used by Sawhney (2006) to categorize process flexibility, and Oke (2005) to explore general manufacturing flexibility. These authors used examples to support their assessment, and this approach continues in the present study in the supporting narrative. 


\subsection{Flexibility assessment procedure}

We based our assessment on the four components of IAMS identified by Eyers and Potter (2015):

1. Design. Activities undertaken from design idea inception to realization as a $3 \mathrm{D}$ design file, including design customization and prototyping,

2. Pre-processing. Activities undertaken before production, including feasibility assessments, design file error-checking, and work scheduling.

3. Manufacturing. Activities undertaken in the physical manufacture of products.

4. Post-processing. Activities undertaken post-manufacture, including cleaning, quality assessment, part collation/assembly, and packing.

We acknowledge that there are many variables that affect flexibility that are difficult to evaluate or control, and situational attributes (e.g. practices at different companies) will directly impact how flexibility is achieved. Flexibility assessment is also subjective; the earliest works on the topic highlight different managers interpret the term differently, and different organizations have different approaches to its attainment (Gerwin 1982). Determination of flexibility is based on multiple factors, of which many (e.g. decision maker views, weighted importance of tasks etc.) may be considered rather judgmental (Brill and Mandelbaum 1989), and so researchers are therefore often reliant on perceptual measures (Corrêa 1994, Vokurka and O'Leary-Kelly 2000) to gauge flexibility.

Mindful of these constraints, the research team evaluated the evidence for each of the twelve cases. Assessments of flexibility were made for each of the seven internal flexibility types, yielding 28 assessments for each case, and 336 for the whole study. We strictly followed the internal flexibility definitions in Table 4, looking for evidence of flexibility, and the nature of the associated penalty. We coded this penalty in terms of its 'class' $(1,2$, or 3$)$, and maintained notes of its derivation. A partial example for Case 2 is provided in the appendix. Upon completion of all assessments, the entire set of results were reviewed as part of the checking process. Pattern matching identified commonality between cases, and narratives developed to explain the results.

The data collection and initial assessment was made by lead researcher, and discussed in review meetings with the co-authors. As part of these meetings brainstorming exercises were used to review the evidence, which is an established technique for team-based analysis of supply chain data (Naim et al. 2002). The team have extensive experience in manufacturing research and practice, enabling the achievement of a detailed critique of the individual cases. This approach promotes consistency between the cases, and overcomes issues of bias arising from individual managers self-evaluating their own systems. Such an approach follows earlier studies that examine flexibility in terms of the organizations implementing it (e.g. Corrêa 1994). 


\section{Flexibility competencies of IAMS}

Table 5 summarizes the internal flexibility assessment, supported by a detailed discussion in the following seven subsections. These findings provide increased specificity regarding the flexibility competencies afforded by IAMS, showing these to arise from a multitude of resources within the manufacturing system, rather than solely from the use of Additive Manufacturing machines. This observation is consistent with manufacturing systems research for conventional technologies, and highlights the importance of a systems-based approach to evaluation. Additionally, for each of the four system components, different internal flexibility types are achieved to different degrees. Again, this is consistent with conventional manufacturing systems, but at odds with many of the literature assumptions that Additive Manufacturing is inherently flexible. 
Table 5: Internal flexibility competency assessment results

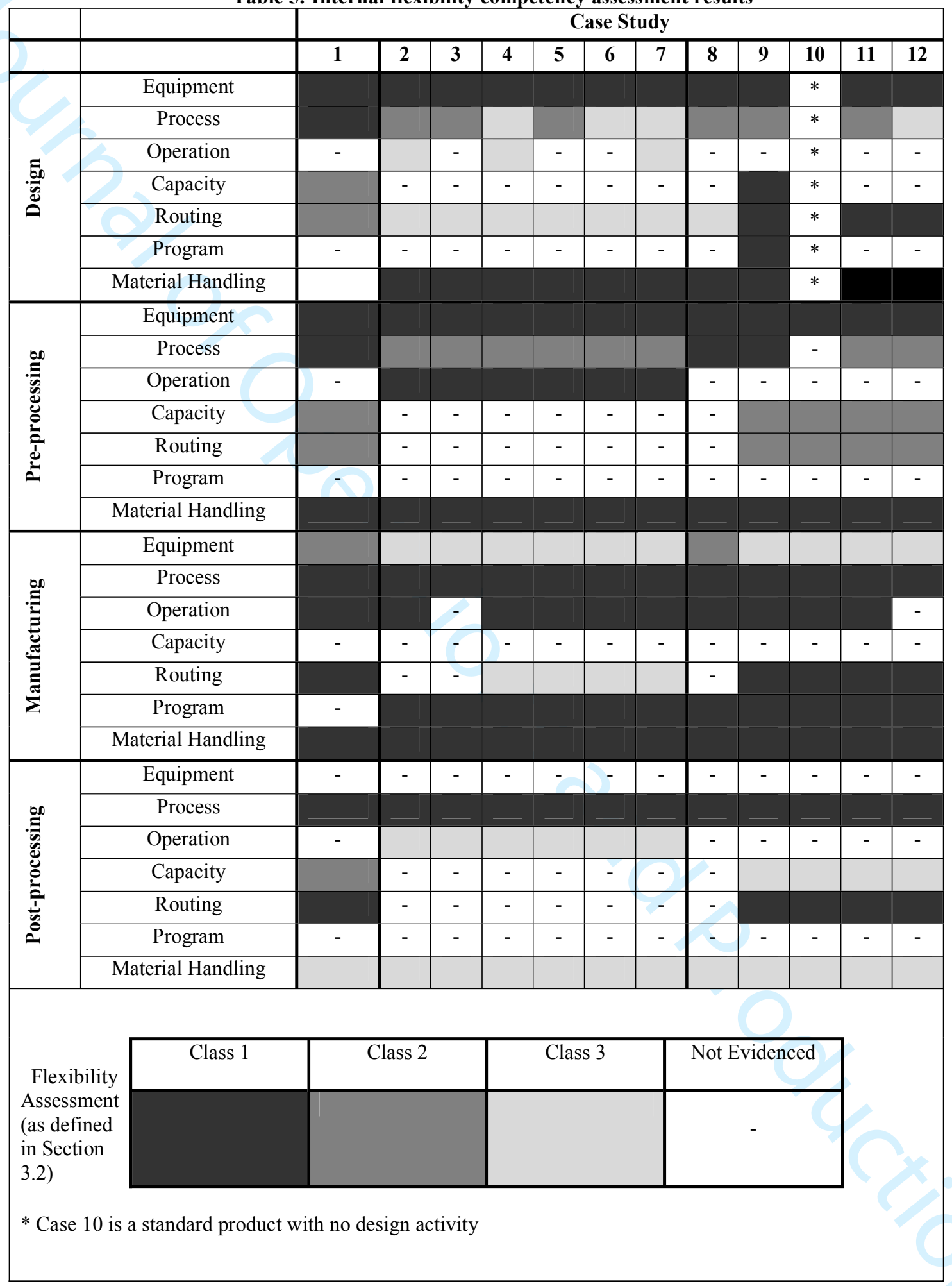




\subsection{Equipment Flexibility}

Equipment flexibility concerns the ability of equipment to change between different operations (Narasimhan and Das 1999). Such change should be achieved without prohibitive effort (Sethi and Sethi 1990); for example due to changeover or setup operations. The cases highlight a disjunction between the internal flexibility achieved by information processing resources (in design and preprocessing), and for physical processing resources (manufacture and post-processing). For example, CAD software in design enables an almost infinite range of opportunities, and similarly preprocessing software can prepare these for manufacture. This is common to all cases (except case 10 where the product is standardized and so the design is predetermined), highlighting that software option shifting has effectively no penalty, but can achieve a very wide range of designs.

By comparison, Additive Manufacturing machines are reliant on human operators to perform setup activities when switching between operations. Common to all cases was the need to prepare the machine by loading materials, demonstrated as a labour-intensive task for all companies. This is exacerbated where material changeover is required, necessitating extensive cleaning of the machine and leading to significant penalty. One exception is Case 1, which uses small Additive Manufacturing machines that are easier to changeover, yielding a smaller penalty. In post-processing material recovery is a manual process requiring much human involvement, which was explicitly noted by companies $\mathrm{B}$ and $\mathrm{C}$ as detracting from a swift and easy changeover, and for all cases the extent of the penalty supported an inflexible classification. Such is the extent of the penalty arising from material changeover that the companies minimised its occurrence, allocating dedicated resources for specific materials.

\subsection{Process flexibility}

Process flexibility refers to the ability to produce parts in the same manufacturing system in different ways (Naim et al. 2006). The cases highlight commonality for penalty-free flexibility in manufacturing and post-processing, with no identified penalty in the production of one part vis-à-vis another. This allows the companies to offer a wide variety of products, as well as the possibility of product customization, but without the penalties often expected in conventional manufacturing. This was shown to be feasible for functional prototypes (case 7), tools (cases 5,6,11), and end-use parts (cases 1-4, 8-10, 12), demonstrating potential for a wide range of applications.

However, constraints were identified in terms of the design and pre-processing activities, where changing products necessitated additional work. Smaller penalties were observed where design was achieved through the reverse-engineering of an existing artefact; in these cases planning activities and error-correction of the scanned artefact lead to a small but notable penalty. As an example, for the 
model ship (case 2), archaeological excavations recovered approximately 700 original artefacts which were 3D scanned and optimized by a skilled technician. By comparison, a much larger penalty was observed where designs were manually designed or manipulated by an operator of 3D software. In case 4, a different architect designed each of the 20 architectural models individually, and the manufacturer manually optimized these in pre-processing for optimal production results. Change between the designs for different products needed highly skilled operators and, with each change, a major setup arises through preparatory activities. Hence whilst changing between different parts was economically feasible, large penalties are observed in design and pre-processing.

Cases such as hearing aids (case 1) and customized lighting (case 9) were shown to eliminate penalties associated with product customization using software configurators. Already popularized for customization in conventional manufacturing (Fogliatto et al. 2012), configurators were feasible where customization could be effectively bounded, and where production volumes merited the initial software investment. For hearing aids the software automatically optimizes much of the design, and makes recommendations to technicians where human decision making is needed. This simplifies and accelerates the design process, whilst simultaneously improving the design quality.

\subsection{Operation flexibility}

Operation flexibility is the ability to change the sequence in which production occurs (Browne et al. 1984). In operation flexibility, activity sequencing is ex-ante (de Toni and Tonchia 1998), with activities assigned in response to the state of the plant. This ability can be useful in optimizing resource usage; by moving work, under-utilized processes may be better exploited, and those under excess loading have their work reduced. In terms of design and pre-processing, we identified different approaches to operation flexibility linked to the individual products. In cases where there was no need for physical prototyping at the design stage (e.g. cases 1, 5, 6, 8-12), companies fixed the sequence in which operations were undertaken to support efficiency and quality in production. In these examples, operations flexibility was neither achieved nor desired; companies used standardization to achieve standard time and resource allocation for all activities. By contrast, where iterations and exploration were required as part of the design process, the sequencing of activities was changed, but this led to large penalties in the efficiency of design creation. Cases 2-4, and 7 all had design iterations in physical prototyping, which led to re-sequencing and repeating of design activities.

In manufacturing, operation flexibility is achieved where machines simultaneously manufacture multiple parts. A well-established capability of Additive Manufacturing, all companies exploited this to improve machine utilization, thereby improving capacity whilst also reducing costs. There is no direct penalty arising from simultaneous manufacture although, for large parts (e.g. cases $3 \& 12$ ), the machine was not physically large enough to accommodate other work. 
Capacity flexibility concerns the ability to increase or decrease production capacity (Naim et al. 2006), normally concerning productive resources including workforce and machinery. Compared to the other flexibility types, the demonstration of capacity flexibility in an IAMS was limited. In the long term, companies $\mathrm{B}$ and $\mathrm{C}$ both identified that changes to capacity could be planned for, and changes to the systems made; however the techniques employed have permanency, either in the physical ownership of new assets (buildings, machines, infrastructure), or the upskilling of workforce. Sunk investments impaired the ability to revert to a lower capacity, and so by Oke's (2005) definition, this represents permanent changeability, rather than flexibility.

However, there is some evidence that larger scale operations are more likely to achieve capacity flexibility. In design, the volume of parts produced merited investment in a software configurator (e.g. cases $1 \& 9$ ); this was able to achieve a wide range of designs without penalty. Similarly, in preprocessing and post-processing, the ability to reallocate staff to different tasks in the larger companies (A \& C) enabled capacity flexibility that was not possible at smaller company B. In manufacturing, the companies studied did not demonstrate capacity flexibility; the need to invest/divest equipment was identified as a long-term factor of changeability.

A lack of capacity flexibility had significant implications for the operations of the companies. Managers identified the nature of demand as both volatile and unpredictable, and something they struggled to accommodate. In practice we saw evidence of demand-levelling activities typical of conventional manufacturing: where spare capacity existed we observed evidence of discounting and rescheduling to keep production busy; conversely where capacity was inadequate lead times were negotiated and orders refused.

\subsection{Routing flexibility}

Routing flexibility is the ability to change the route taken by parts through the production process (Browne et al. 1984). Originally this definition asserted that routing flexibility was employed in response to equipment breakdowns, however other studies have shown this flexibility type may also be exploited to accommodate 'rush jobs' by using alternate equipment.

A key determinant of routing flexibility is the availability of alternate resources, and this was closely linked to the size of the company. The larger companies A and $\mathrm{C}$ both enjoyed duplication of most resources, allowing work to be reallocated without significant penalty. By comparison Company B had fewer instances of resources (sometimes just 1), which hindered the ability of routing flexibility. Furthermore, all companies identified penalties where routing flexibility called upon resources in an 
inefficient manner. For example, skilled staff performing semi-skilled work were acknowledged to be underutilized, whilst semi-skilled staff performing skilled work was either infeasible, or achieved inferior output. Companies acknowledged such penalties to exist, but be tolerable.

For some cases flexibility was inhibited by operational decisions intended to uphold other competitive objectives. For example, in the production of surgical guides (case 8), specially-tuned machines to afford the highest possible quality output were utilized. In this case, the high production volumes justified the establishment of dedicated resources. Whilst this approach does therefore constrain flexibility, it does focus on the achievement of quality in the parts produced.

\subsection{Program flexibility}

Program flexibility concerns the ability of equipment to operate unattended for extended periods of time (Sethi and Sethi 1990), which Jaikumar (1986) consider as whole shifts or overnight. Whilst there has been much enthusiasm for Additive Manufacturing to support unattended production, this study finds ongoing human involvement is necessary in almost all activities undertaken, and overall there is little evidence of program flexibility being achieved. Most design and pre-processing activities were reliant on human input; likewise post-processing activities typically required extensive manual labour involvement.

Two notable exceptions support program flexibility. Firstly, in the production of customized lighting (case 9) a web-based configurator helped customers configure parts, which runs unattended to achieve program flexibility in design. The second exception concerns the unattended operation of the Additive Manufacturing machines, where once started by a human operator no further involvement is required until the build is complete. This applies to all large-scale Additive Manufacturing machines, as demonstrated in cases 2-12.

\subsection{Material handling flexibility}

Material handling flexibility concerns the ability for materials to move effectively through the system (Sethi and Sethi 1990) and is often taken to include the automated movement of parts through different production processes within a manufacturing system. Within this study, material was delimited in terms of these physical materials, but also the information that is requisite for production.

Where information is 'digital' and moves through computer networks we found no notable penalty arising from the production of one part to another, principally in the design and pre-processing activities. The only notable exception occurs where data cannot be transferred electronically; for example, in hearing aid production (case 1), the manufacturer was reliant upon the transfer of data through the postal network. Similarly, since Additive Manufacturing machines produce whole parts 
(rather than relying on multiple distinct manufacturing processes), there was no penalty observed in production of one part relative to another, supporting a high degree of material handling flexibility.

Material handling flexibility was significantly constrained in post-processing as a result of the labour resources involved. For each part technicians demonstrated the need to plan and implement several different interventions to complete the part; this resulted in a large (but often tolerable) penalty.

\section{Flexibility capabilities of IAMS}

As explained in Section 2.1, achieving internal flexibility competencies in manufacturing systems enables the external flexibility capabilities that satisfy customer demand. Linking the external capabilities and internal competencies identified in this study, this section explores the relevance and enablement of the seven external capabilities, highlighting potentially emergent opportunities not explicitly explored in current literature. Looking forward, in Section 5.4 we consider how management can leverage the findings of this work in developing the flexibility of their own Additive Manufacturing facilities, highlighting the importance of education and training to support the workforce.

\subsection{Capability relevance}

The literature review identified seven potential external flexibility capability definitions, and through the empirical research we looked for capability relevance: is the identified capability evidenced, or does the potential exist for exploitation? We compared each of capability definitions with the case study evidence, summarizing the results in Table 6 . For each capability we show the number of cases where it was evidenced in practice, identified as a potential opportunity (but not evidenced), or where we could find no support for the capability from the case study research.

For six of the seven external flexibility capabilities the alignment with literature is either moderate or strong, being relevant to most cases. This finding serves to underline both the relevance of these capabilities, and that the nature of flexibility in IAMS is the result of a multitude of different capabilities. The remaining external flexibility capability concerning the usage of many different materials was notable in its lack of evidence (or potential for uptake). Whilst the literature supported this, in practice the associated penalties meant that companies avoided this capability. Changing material often required design and pre-processing changes (to accommodate the different material properties) and had large set-up costs for manufacturing and post-processing. As a result, companies $\mathrm{A}$ and $\mathrm{B}$ did not switch between materials, and company $\mathrm{C}$ dedicated resources to specific materials to minimize changeovers. 


\subsection{Capability enablement}

To understand how the external capabilities are achieved, each of the seven external flexibility capabilities was examined in terms of the principal internal enabling competencies. We considered the relevant cases (as identified in Section 5.1), and reviewed the internal competencies that were achieved within them. Whilst many competencies may contribute, the objective was to identify the principal internal competencies that enabled the focal external capability. With this knowledge, companies can prioritize efforts to achieve specific competencies in their manufacturing systems.

Table 6 shows that equipment and process competencies were by far the most common capability enablers, with one or both needed for each of the identified external capabilities. Without process or equipment flexibility it would be difficult for the manufacturing systems to achieve the external flexibility capabilities, and they therefore make an essential contribution to the achievement of flexibility within IAMS. The attainment of these flexibilities was shown in Section 4 to exist for most components of the manufacturing system; equipment flexibilities being most readily achieved in design and pre-processing, whilst process flexibility achieved for manufacturing and post-processing.

\subsection{Emergent Capabilities}

To be useful, internal flexibility competencies need to support the achievement of external flexibility capabilities that can lead to products that are valued by customers. Whilst equipment and process flexibilities are important enablers of the seven identified external flexibility capabilities, Section 4 has shown that IAMS may achieve other internal flexibility competencies. If these did not link to external capabilities then their achievement would be futile; the system would have flexibilities that served no valuable purpose. The case studies indicate that rather than being of no use, these internal competencies may support five flexibility capabilities that have not previously been identified in the Additive Manufacturing literature, which we term as 'emergent capabilities'

1. Capability to re-sequence work within the manufacturing system: Whilst many activities are normally undertaken in sequence, flexibility in pre-processing and manufacturing can allow companies to respond to demand requirements, for example by reprioritizing the fulfilment of orders. Operations flexibility competencies supported this capability, allowing the ordering of work to change and in some cases, routing flexibility to change the path work takes through the manufacturing system.

2. Capability to vary the volume of production: Most existing Additive Manufacturing studies focus on the production of low-volume and custom parts, neglecting to consider the aggregate production of the system. The current study found many cases to have volatile and unpredictable demand, requiring the manufacturing system to adapt accordingly through the attainment of capacity flexibility 
competencies. Whilst fixed plant resources were shown to be largely inflexible, this study found evidence of labour resources supporting this flexibility competence by moving between different jobs and exploiting multi-skilling, enabling companies to respond to changing demand. Such abilities are often evidenced for conventional manufacturing technologies, but largely unreported for IAMS.

3. Capability to improve system resilience: Whilst Additive Manufacturing machines are wellacknowledged to have reliability issues, little research emphasis has considered how to overcome failure without affecting production output. Conventional manufacturing often employs routing flexibility to move work from failed system resources and for IAMS, Companies A \& $\mathrm{C}$ also demonstrated their ability to achieve routing flexibility competencies. This is, however, contingent on having spare capacity to accommodate the work; Company B did not enjoy this facility, and so work could not be routed to alternate resources. This led to several instances where customer orders could not be satisfied, highlighting the consequences of a lack of a system resilience capability.

4. Capability for unattended production: The necessity of labour and other non-machine resources constrains the ability for an automated, 'lights-out' manufacturing system, however the potential for the individual Additive Manufacturing machines to run un-attended is well-documented and for some machines evidenced in practice. For this component of the manufacturing system, this is a good example of the attainment of a program flexibility competence. Once machines are loaded with materials they fabricate unattended for tens of hours and can be left to run overnight and at weekends without human supervision. A lack of feedback from the machines tends to mean that human observers keep a watchful eye during normal operating times, though this was not critical for operations.

5. Capability for the achievement of a smooth material flow: As with conventional manufacturing systems, IAMS are reliant on both material and information to operate, and ideally this should flow smoothly without interruptions. Within this study the digital nature of design information, together with the automation of material processing by the Additive Manufacturing machine offers the potential to achieve a material handling flexibility competence, contributing to a smooth flow of information and material throughout the system.

\subsection{Management implications for developing flexibility within Additive Manufacturing operations}

As reported in Table 3, the companies that contributed to this research were well-established, but through the interviews we learnt that their introduction to Additive Manufacturing had been fraught with difficulties. Company A reported that the capacity of their first machine was too large, and could not be changed (i.e. a capacity flexibility problem). Company B offered many different Additive Manufacturing technologies, but for some only had one machine installed; when this failed work 
could not be switched to other machines and customers were disappointed (i.e. a routing flexibility problem). Company $\mathrm{C}$ allowed customers to design their own novelty products, but found that most of these needed substantial correction before manufacture; this took much effort for the skilled labour to adapt to the various products (i.e. a process flexibility problem).

These examples illustrate the companies learning through their mistakes regarding the adoption of Additive Manufacturing. It should, however, be remembered that when these companies were starting out the industry was in its infancy, with far fewer companies competing for business. Today, Additive Manufacturing is a very competitive industry, and although the Additive Manufacturing machines offer impressive abilities, as evidenced in this study there remains a great need for human skill in its operation and management. Operators need to understand how best to use the technologies, and at managerial level an understanding of techniques to yield strategic advantage is essential for ongoing competitiveness. There is, however, a general lack of skills training for Additive Manufacturing (Anonymous 2016), with Higher Education training typically post-graduate in its nature (Minetola et al. 2015). Consistent with current trends in research, such training tends to focus on technical, rather than managerial skills. However, as with other manufacturing and information technologies (e.g. computers, internet etc), it is reasonable to expect some redress to this training imbalance as Additive Manufacturing becomes increasingly prevalent. Education providers therefore need to be ready to provide training in the management of Additive Manufacturing, drawing on the research Operations Management scholars have already undertaken.

For managers wishing to achieve a strategic advantage through flexibility, the current study offers some useful insights. Fundamentally, there is the need to think about flexibility as an internal competency of the operation, and to evaluate requirements carefully with the requirements of its environment (Lloréns et al. 2005). Therefore, it is important that the most appropriate strategy is pursued. For companies with a good understanding of flexibility, focusing on specific flexibility types would direct efforts towards the development of flexibility competencies. By comparison, for those companies less certain of flexibility it would be worthwhile to consider the external view of capabilities, in order to evaluate the desired outcomes. Once understood, companies can enact strategies to achieve appropriate internal competencies.

Within this work we provide a 'penalty of change' based assessment technique that can be applied in different Additive Manufacturing facilities, allowing managers to readily identify constraints and develop solutions to overcome these. For newcomers to Additive Manufacturing this could serve to help design their manufacturing systems, whilst established companies could employ it for ongoing benchmarking or in planning for the future. 


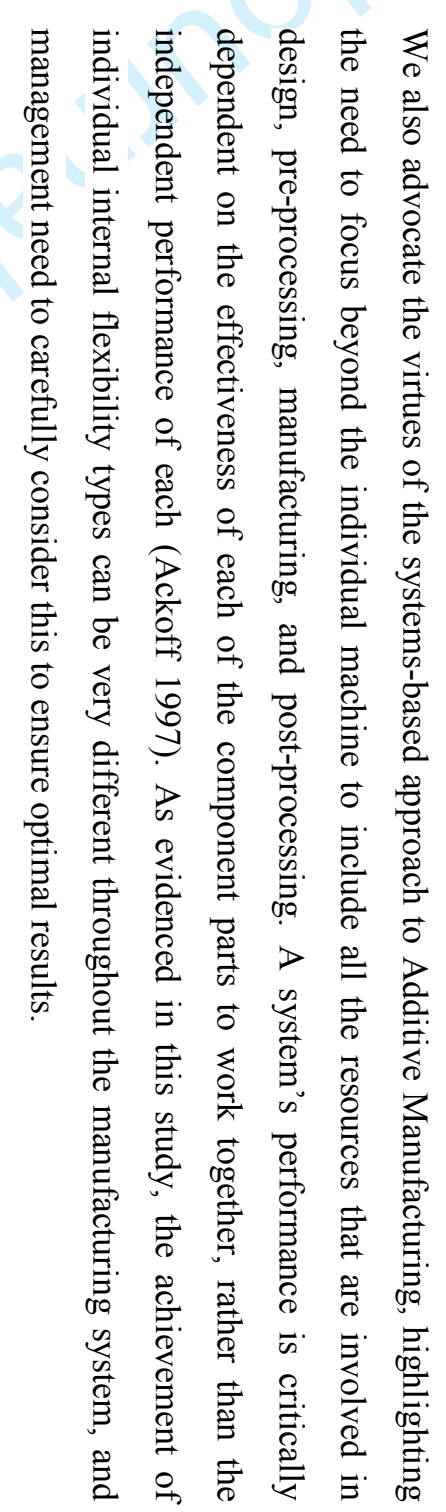




\section{Table 6: Internal competence and external capability alignment}

\begin{tabular}{|c|c|c|c|c|c|c|c|c|c|}
\hline & & \multirow[b]{2}{*}{ Empirical support from case studies } & \multicolumn{7}{|c|}{ Principal flexibility competencies } \\
\hline \multirow{8}{*}{ 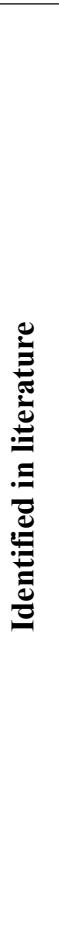 } & $\begin{array}{c}\text { Flexibility } \\
\text { capabilities }\end{array}$ & & $\begin{array}{l}\text { च्च } \\
\text { 言 } \\
\text { ज्ञ }\end{array}$ & 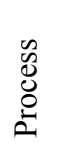 & 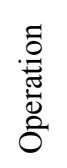 & 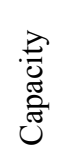 & 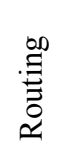 & 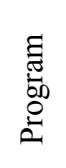 & 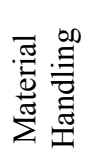 \\
\hline & $\begin{array}{l}\begin{array}{l}\text { On-demand } \\
\text { production }\end{array} \\
\end{array}$ & $\begin{array}{l}\text { Evidenced (8) Potential (4) Unsupported (0) } \\
\text { Moderately evidenced for low-volume production in short production runs and/or quick production. However, spare } \\
\text { capacity required in all elements of the system to truly produce on-demand, which decreases overall performance. }\end{array}$ & $\nabla$ & $\nabla$ & & $\nabla$ & & & \\
\hline & $\begin{array}{l}\text { Freedom in design } \\
\text { practice }\end{array}$ & 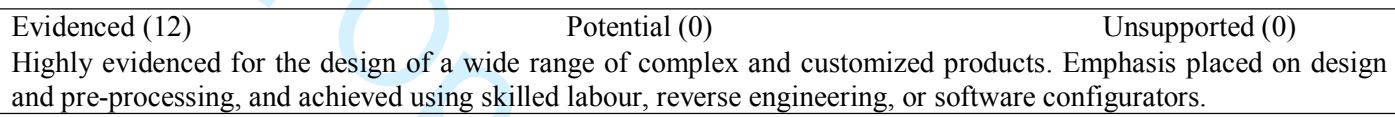 & 甲 & $\nabla$ & & & & & \\
\hline & $\begin{array}{l}\text { Production of a wide } \\
\text { range of parts }\end{array}$ & $\begin{array}{l}\text { Evidenced (9) } \\
\text { Moderately evidenced to produce a wide range of parts, or the potential to achieve these through manufacturing and } \\
\text { post-processing. }\end{array}$ & $\nabla$ & $\nabla$ & & & & & \\
\hline & $\begin{array}{l}\text { Production of } \\
\text { complex geometries }\end{array}$ & $\begin{array}{l}\text { Evidenced (12) Potential }(0) \\
\text { Highly evidenced for the design and production of complex shaped parts. Complex geometries do not affect pre- } \\
\text { processing or manufacturing, but do increase labour workload in both design and post-processing. }\end{array}$ & $\nabla$ & $\nabla$ & & & & & \\
\hline & $\begin{array}{l}\text { Ability to use range } \\
\text { of materials }\end{array}$ & $\begin{array}{l}\text { Evidenced (1) Potential (1) } \\
\text { Unsupported (10) } \\
\text { post-pridencessing, together with costly machine changeovers in manufacturing. }\end{array}$ & $\nabla$ & & & & & & ఐ \\
\hline & \begin{tabular}{|l|} 
Elimination of \\
tooling in production
\end{tabular} & \begin{tabular}{lc}
\multicolumn{1}{c}{ Evidenced (12) } & Potential $(0)$ \\
Highly evidenced with no requirement for tooling in any cases. & Unsupported (0) \\
\end{tabular} & $\nabla$ & $\nabla$ & & & & & \\
\hline & $\begin{array}{l}\text { Exploit process } \\
\text { variables for efficient } \\
\text { production }\end{array}$ & $\begin{array}{l}\text { Evidenced (12) } \quad \text { Potential }(0) \\
\text { Highly evidenced with all cases having process variables set in pre-processing and manufacturing for optimal part } \\
\text { production. }\end{array}$ & $\nabla$ & $\nabla$ & & & & & \\
\hline & $\begin{array}{l}\text { Capability to re- } \\
\text { sequence work }\end{array}$ & $\begin{array}{l}\text { Evidenced (5) Potential (4) } \\
\text { Moderate evidence of work being re-routed in larger operations, but potential opportunities also identified in } \\
\text { resequencing. }\end{array}$ & $\nabla$ & $\nabla$ & $\nabla$ & & $\nabla$ & & \\
\hline 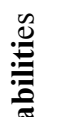 & $\begin{array}{l}\text { Capability to vary the } \\
\text { volume of production }\end{array}$ & $\begin{array}{l}\text { Evidenced (4) Potential (3) } \\
\text { Limited evidence of capability achieved in practice due to fixed resource constraints, but opportunities identifiable } \\
\text { to gain flexibility through labour resources. }\end{array}$ & & $\nabla$ & & $\nabla$ & & & \\
\hline 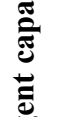 & $\begin{array}{l}\text { Capability to improve } \\
\text { system resilience }\end{array}$ & $\begin{array}{l}\text { Evidenced (5) Potential (0) } \\
\text { Moderate evidence where additional routes available and } \text { where products can be manufactured using general } \\
\text { purpose manufacturing resources. }\end{array}$ & $\nabla$ & $\nabla$ & & & $\nabla$ & & \\
\hline 莺 & \begin{tabular}{|l|l|l} 
Capability for \\
unattended \\
production
\end{tabular} & $\begin{array}{l}\text { Evidenced (0) Potential (3) } \\
\text { Not directly evidenced, but realistic opportunities exist to achieve using software tools and automation of post- } \\
\text { processing for three products. }\end{array}$ & & $\nabla$ & & & & $\nabla$ & \\
\hline & $\begin{array}{l}\text { Capability for the } \\
\text { achievement of a } \\
\text { smooth material flow }\end{array}$ & $\begin{array}{l}\text { Evidenced (11) Potential (1) } \\
\text { Highly evidenced for electronic information resources and materials in manufacturing, but often somewhat } \\
\text { constrained by the manual nature of post-processing. }\end{array}$ & $\nabla$ & $\nabla$ & & 6 & & & 甲 \\
\hline
\end{tabular}


2

3

4

5

6

7

8

9

10

11

12

13

14

15

16

17

18

19

20

21

22

23

24

25

26

27

28

29

30

31

32

33

34

35

36

37

38

39

40

41

42

43

44

45

46

\section{Legend}

Evidenced (n): Number of cases that demonstrated the literature capability in practise.

Potential (n): Number of cases that showed the potential to achieve the capability, but it was not shown in practise.

Unsupported (n): Number of cases that did not evidence or show potential to achieve the capability in practise. 


\section{Discussion and Conclusion}

This paper has provided a first detailed study on the strategically important concept of flexibility in an Additive Manufacturing context. A thorough literature review examined how the established Operations Management concept of flexibility has been applied to Additive Manufacturing. Existing Additive Manufacturing research often uses the term 'flexibility', but with little precision regarding its meaning or implications. Using this literature, and drawing upon established Operations Management principles on flexibility, the paper has increased the specificity with which flexibility in an Additive Manufacturing context is understood, moving from somewhat vague comments in terms of the machines, to a detailed explanation that delimits flexibility in terms of the capabilities (observed externally), and the competencies (achieved internally).

Two research questions satisfied the research aim, and we take this opportunity to revisit these in this closing section of the paper.

Research Question 1: How can flexibility competencies and capabilities be empirically assessed for an Industrial Additive Manufacturing System?

To understand the internal flexibility competencies of Additive Manufacturing, this study has developed a detailed typology using well-established flexibility types in Operations Management research. Additionally, providing a qualitative assessment technique allows a categorical assessment of each flexibility type. Employing these together to examine the nature of twelve case studies allowed a detailed consideration of the distinct types of flexibility that can be achieved, the characteristics of IAMS that support flexibility, and the inhibitors that hinder it. Combining these findings with the detailed review of the literature, we identified seven distinct external flexibility capabilities, six of which this empirical research has evidenced. Flexibility is a highly relevant attribute for Additive Manufacturing operations, underlining that the attainment of flexibility such as 'on-demand manufacturing' can bring practical benefits, and illustrating the specific internal flexibility competencies needed to achieve these.

Research Question 2: How is the flexibility of an Industrial Additive Manufacturing System influenced by the enabling or inhibiting of different flexibility types?

The combination of theoretical and empirical research undertaken in this study has allowed an initial evaluation on the extent to which an IAMS may attain flexibility. As recognized in the literature review, many authors have claimed Additive Manufacturing is 'flexible' but have not explained how or why this may be. This study has explored this assertion in detail, finding many supporting characteristics for flexibility, but also some significant constraints. Flexibility of IAMS is complex, multifarious, and enabled by a multitude of system resources. This finding contrasts somewhat with 
There are good reasons for exploring flexibility in this manner and to this level of detail. Flexibility is well-established as one of the fundamental objectives that can lead to competitive advantage for companies, and as Additive Manufacturing becomes increasingly important for contemporary manufacturing, so too does the requirement to achieve flexibility. However, history has already demonstrated that poor understanding of flexibility has meant that it cannot be fully exploited by managers, and by providing a detailed method for defining and assessing flexibility in this context, this paper therefore contributes an effective means for researchers to further explore flexibility, and for practitioners (both new and existing) to consider when implementing it. This is particularly pertinent given the high rate of adoption of the technologies, leading to inexperienced users faced with the challenge of achieving appropriate flexibility characteristics within their operations.

the has focused principally on individual Additive Manufacturing machines, and on individual external flexibility capabilities.

Taking a systems perspective, this study has evaluated how the operations enabled or inhibited each of seven internal flexibility competencies, and these are discussed in Section 4 and summarized in Table 5. From the narrative, it is noted that there are some case-specific results, but from the breadth of cases explored, some general conclusions about the flexibility of an IAMS can be drawn. From the internal perspective, IAMS tend to enjoy high degrees of equipment and material handling internal flexibilities for Design and Pre-processing, but due to the highly laborious nature of the work undertaken, program flexibilities are seldom achieved. In terms of IAMS Manufacturing, the abilities of the AM machines achieved process, operation, and program flexibilities to a high degree, but the fixed and expensive nature of the machine infrastructure inhibits capacity flexibility. Post-processing observed flexibility the least often, with only process flexibilities achieved to a high degree. What these findings underline is that based on evidence from industry, to offer flexibility companies need to effectively achieve a range of internal flexibility competencies throughout the whole manufacturing system, not just through the operations of individual machines. Without this perspective, flexibility bottlenecks will arise, and the overall output of the system will be constrained by individual systems components. The case research supports a view that flexibility in IAMS is therefore not necessarily an inherent characteristic; companies need to think carefully about what types of flexibility are required, and leverage the resources of entire system to support this. This finding is important, since the ability to achieve flexibility in manufacturing will be necessary to achieve many future scenarios employing Additive Manufacturing including successful Mass Customization (Fogliatto et al. 2012), together with the viable on-demand production of products (Economist 2011) and spare parts (Foresight 2013; Holmström et al. 2010). 
We acknowledge that exploratory studies such as this do lead to constraints in the research. Flexibility is well-established as a difficult concept to evaluate (Oke, 2005), and despite the careful approach taken in this study, we must acknowledge that contingent factors do have the potential to affect the determination of flexibility for Additive Manufacturing. For example, idiosyncrasies in the way individual operations are organized and operate may arise through the strategic choices made by managers; these in turn might be affected by the macro forces that the organization faces. Such factors could be explored by using the PESTEL analysis tool (concerning Political, Economic, Social, Technological, Environmental, and Legal factors), but in practice it would be extremely difficult to meaningfully develop flexibility assessment approaches that could fully accommodate these factors for all contexts. Furthermore, whilst the qualitative case-based approach has enabled an in-depth evaluation of twelve different cases, it is constrained in terms of its sample size because of the extensive resource requirements of this type of research. Further work is needed to broaden the range of cases examined, focusing particularly on novel mechanisms employed in the achievement of different internal flexibility competencies. This would be helpful to understand better any contextual factors arising in the achievement of flexibility.

The current study has focused on the flexibilities currently evidenced by an IAMS with consideration of the interfaces with suppliers and customers. Nevertheless, there is further research required for due consideration of a whole supply chain perspective such as the interplay with vendor and sourcing flexibility. 


\section{References}

Ackoff, R. L. (1997), Systems, messes and interactive planning, In: Trist, E. et al. eds. The societal engagement of social science. Vol. 3. Philidelphia: University of Philidelphia Press.

Alp, O. and Tan, T. (2008), "Tactical capacity management under capacity flexibility", IIE Transactions 40(3), pp. 221-237.

Alpern, P. (2010), Beam me up a part, Scotty [Online]. Available at: http://www.industryweek.com/product-development/beam-me-part-scotty [Accessed: 6 October 2015].

Anonymous. (2016), UK National Strategy for Additive Manufacturing: Update Report 2 [Online]. Available at: $\quad$ http://www.amnationalstrategy.uk/wp-content/uploads/2015/05/UK-AM-National-StrategyUpdate-Report-2.2.pdf [Accessed: 12 May 2017].

Bak, D. (2003), "Rapid prototyping or rapid production? 3D printing processes move industry towards the latter", Assembly Automation 23(4), pp. 340-345.

Bateman, N. (1999), "Measuring the mix response flexibility of manufacturing systems", International Journal of Production Research 37(4), pp. 871-880.

Beach, R., Muhlemann, A. P., Price, D. H. R., Paterson, A. and Sharp, J. A. (2000), "A review of manufacturing flexibility", European Journal of Operational Research 122(1), pp. 41-57.

Benjaafar, S. and Ramakrishnan, R. (1996), "Modelling, measurement and evaluation of sequencing flexibility in manufacturing systems", International Journal of Production Research 34(5), pp. 1195-1220.

Bernardes, E. S. and Hanna, M. D. (2009), "A theoretical review of flexibility, agility and responsiveness in the operations management literature: Toward a conceptual definition of customer responsiveness", International Journal of Operations \& Production Management 29(1), pp. 30-53.

Bourell, D. L., Leu, M. C., Chakravarthy, K., Guo, N. and Alayavalli, K. (2011), "Graphite-based indirect laser sintered fuel cell bipolar plates containing carbon fiber additions", CIRP Annals - Manufacturing Technology 60(1), pp. 275-278.

Boyer, K. K. and Leong, G. K. (1996), "Manufacturing flexibility at the plant level", Omega 24(5), pp. 495-510.

Brandl, E., Heckenberger, U., Holzinger, V. and Buchbinder, D. (2012), "Additive manufactured AlSi10Mg samples using Selective Laser Melting (SLM): Microstructure, high cycle fatigue, and fracture behavior", Materials \& Design 34, pp. 159-169.

Brennan, L., Ferdows, K., Godsell, J., Golini, R., Keegan, R., Kinkel, S., Srai, J., S. and Taylor, M. (2015), "Manufacturing in the world: where next?", International Journal of Operations \& Production Management 35(9), pp. 1253-1274.

Brenne, F., Niendorf, T. and Maier, H. J. (2013), "Additively manufactured cellular structures: Impact of microstructure and local strains on the monotonic and cyclic behavior under uniaxial and bending load", Journal of Materials Processing Technology 213(9), pp. 1558-1564. 
Brill, P. H. and Mandelbaum, M. (1989), "On measures of flexibility in manufacturing systems", International Journal of Production Research 27(5), pp. 747-756.

Browne, J., Dubois, D., Rathmill, K., Sethi, S. P. and Stecke, K. E. 1984. Types of flexibilities and classification of flexible manufacturing systems. Working Paper 367. University of Michigan.

Byrne, M. D. and Chutima, P. (1997), "Real-time operational control of an FMS with full routing flexibility", International Journal of Production Economics 51(1), pp. 109-113.

Canellidis, V., Giannatsis, J. and Dedoussis, V. (2013), "Efficient parts nesting schemes for improving stereolithography utilization", Computer-Aided Design 45(5), pp. 875-886.

Chhabra, M. and Singh, R. (2011), "Rapid casting solutions: a review", Rapid Prototyping Journal 17(5), pp. 328-350.

Childerhouse, P., Aitken, J. and Towill, D. R. (2002), "Analysis and design of focused demand chains", Journal of Operations Management 20(6), pp. 675-689.

Chimento, J., Highsmith, M. J. and Crane, N. (2011), "3D printed tooling for thermoforming of medical devices", Rapid Prototyping Journal 17(5), pp. 387-392.

Choe, P., Tew, J. D. and Tong, S. (2015), "Effect of cognitive automation in a material handling system on manufacturing flexibility", International Journal of Production Economics 170(Part C), pp. 891-899.

Corrêa, H. L. (1994), Linking flexibility, uncertainty and variability in manufacturing systems: managing unplanned change in the automotive industry, Aldershot: Avebury.

Cousens, A., Szwejczewski, M. and Sweeney, M. (2009), "A process for managing manufacturing flexibility", International Journal of Operations \& Production Management 29(4), pp. 357-385.

Craeghs, T., Bechmann, F., Berumen, S. and Kruth, J.-P. (2010), "Feedback control of Layerwise Laser Melting using optical sensors", Physics Procedia 5(Part B), pp. 505-514.

D'Aveni, R. (2015), "The 3-D printing revolution", Harvard Business Review 93(5), pp. 40-48.

Dadbakhsh, S., Hao, L., Jerrard, P. G. E. and Zhang, D. Z. (2012), "Experimental investigation on selective laser melting behaviour and processing windows of in situ reacted $\mathrm{Al} / \mathrm{Fe} 2 \mathrm{O} 3$ powder mixture", Powder Technology 231, pp. 112-121.

Das, A. (2001), "Towards theory building in manufacturing flexibility", International Journal of Production Research 39(18), pp. 4153-4177.

Das, S. K. and Nagendra, P. (1997), "Selection of routes in a flexible manufacturing facility", International Journal of Production Economics 48(3), pp. 237-247.

de Neufville, R. and Scholtes, S. (2011), Flexibility in engineering design, Cambridge, MA: MIT Press. 
de Toni, A. and Tonchia, S. (1998), "Manufacturing flexibility: a literature review", International Journal of Production Research 36(6), pp. 1587-1617.

Domingo, R., Alvarez, R., Peña, M. M. and Calvo, R. (2007), "Materials flow improvement in a lean assembly line: a case study", Assembly Automation 27(2), pp. 141-147.

Eisenhardt, K. M. and Graebner, M. E. (2007), “Theory building from cases: Opportunities and challenges.” The Academy of Management Review 50(1), pp. 25-32.

Economist (2011), "Print me a Stradivarius", The Economist 398, p. 11.

European Commission (2014), Additive Manufacturing in FP7 and Horizon 2020, Brussels, Belgium:

Eyers, D. R. and Dotchev, K. D. (2010), "Technology review for mass customisation using rapid manufacturing", Assembly Automation 30(1), pp. 39-46.

Eyers, D. R. and Potter, A. T. (2015), "E-commerce channels for Additive Manufacturing: An Exploratory Study", Journal of Manufacturing Technology Management 26(3), pp. 390-411.

Fisher, M., Hammond, J., Obermeyer, W. and Raman, A. (1997), "Configuring a supply chain to reduce the cost of demand uncertainty", Production and Operations Management 6(3), pp. 211-225.

Fogliatto, F. S., Da Silveira, G. and Borenstein, D. (2012), "The mass customization decade: An updated review of the literature", International Journal of Production Economics 138(1), pp. 14-25.

Ford, S. J., Routley, M. J., Phaal, R. and Probert, D. R. (2014), "The industrial emergence of commercial inkjet printing", European Journal of Innovation Management 17(2), pp. 126-143.

Foresight (2013), The future of manufacturing: A new era of opportunity and challenge for the UK, London: The Government Office for Science.

Francas, D., Löhndorf, N. and Minner, S. (2011), "Machine and labor flexibility in manufacturing networks", International Journal of Production Economics 131(1), pp. 165-174.

Furumoto, T., Ueda, T., Amino, T., Kusunoki, D., Hosokawa, A. and Tanaka, R. (2012), "Finishing performance of cooling channel with face protuberance inside the molding die", Journal of Materials Processing Technology 212(10), pp. 2154-2160.

Gerwin, D. (1982), "Do's and don'ts of computerized manufacturing", Harvard Business Review 60(2), pp. 107116.

Gerwin, D. (1987), "An agenda for research on the flexibility of manufacturing processes", International Journal of Operations \& Production Management 7(1), pp. 38-49.

Ghadge, A., Dani, S. and Kalawsky, R. (2012), "Supply chain risk management: present and future scope", The International Journal of Logistics Management 23(3), pp. 313-339. 
Glardon, R., Karapatis, N., Romano, V. and Levy, G. N. (2001), "Influence of Nd:YAG parameters on the Selective Laser Sintering of metallic powders", CIRP Annals - Manufacturing Technology 50(1), pp. 133-136.

Grzesiak, A., Becker, R. and Verl, A. (2011), "The Bionic Handling Assistant: a success story of additive manufacturing", Assembly Automation 31(4), pp. 329-333.

Gupta, D., Gerchak, Y. and Buzacott, J. A. (1992), "The optimal mix of flexible and dedicated manufacturing capacities: Hedging against demand uncertainty", International Journal of Production Economics 28(3), pp. 309-319.

Heralić, A., Christiansson, A.-K. and Lennartson, B. (2012), "Height control of laser metal-wire deposition based on iterative learning control and 3D scanning", Optics and Lasers in Engineering 50(9), pp. 1230-1241.

Hill, T. and Chambers, S. (1991), "Flexibility - a manufacturing conundrum", International Journal of Operations \& Production Management 11(2), pp. 5-13.

Holmström, J., Partanen, J., Tuomi, J. and Walter, M. (2010), "Rapid manufacturing in the spare parts supply chain: Alternative approaches to capacity deployment", Journal of Manufacturing Technology Management 21(6), pp. 687-697.

Hutchinson, G. K. and Pflughoeft, K. A. (1994), "Flexible process plans: their value in flexible automation systems", International Journal of Production Research 32(3), pp. 707-719.

Hyun, J.-H. and Ahn, B.-H. (1992), "A unifying framework for manufacturing flexibility", Manufacturing Review 5(4), pp. 251-260.

Jaikumar, R. (1986), "Postindustrial manufacturing", Harvard Business Review 64(6), pp. 69-76.

Jain, A., Jain, P. K., Chan, F. T. S. and Singh, S. (2013), "A review on manufacturing flexibility", International Journal of Production Research 51(19), pp. 5496 - 5970.

Jiang, K., Guo, Y., Bourell, D. L., Zeng, W. and Li, Z. (2013), "Study on Selective Laser Sintering of eucalyptus/PES blend and investment casting technology", Procedia CIRP 6, pp. 510-514.

Jin, G. Q., Li, W. D., Gao, L. and Popplewell, K. (2013), "A hybrid and adaptive tool-path generation approach of rapid prototyping and manufacturing for biomedical models", Computers in Industry 64(3), pp. 336-349.

Karevan, M., Eshraghi, S., Gerhardt, R., Das, S. and Kalaitzidou, K. (2013), "Effect of processing method on the properties of multifunctional exfoliated graphite nanoplatelets/polyamide 12 composites", Carbon 64, pp. 122-131.

Kumar, M. and Choudhury, A. R. (2002), "Adaptive slicing with cubic patch approximation", Rapid Prototyping Journal 8(4), pp. 224-232.

Kuo, C. C. and Su, S. J. (2013), "A cost-effective approach for rapid manufacturing a low pressure wax injection mold with high surface finish and high dimensional accuracy", Materialwissenschaft Und Werkstofftechnik 44(4), pp. 330-339.

Leong, G. K., Snyder, D. L. and Ward, P. T. (1990), "Research in the process and content of manufacturing strategy", OMEGA: International Journal of Management Science 18(2), pp. 109-122. 
Levy, G. N., Schindel, R. and Kruth, J. P. (2003), "Rapid Manufacturing and Rapid Tooling with layer manufacturing technologies, state of the art and future perspectives", CIRP Annals - Manufacturing Technology 52(2), pp. 589-609.

Lloréns, F. J., Molina, L. M. and Verdú, A. J. (2005), "Flexibility of manufacturing systems, strategic change and performance", International Journal of Production Economics 98(3), pp. 273-289.

Ma, M., Wang, Z., Wang, D. and Zeng, X. (2013), "Control of shape and performance for direct laser fabrication of precision large-scale metal parts with 316L Stainless Steel", Optics \& Laser Technology 45, pp. 209-216.

MacCarthy, B. L., Blome, C., Olhager, J., Srai, J. S., Zhao, Z. (2016), "Supply chain evolution - theory, concepts and science", International Journal of Operations \& Production Management, 36(12), pp. 1696-1718.

Matthews, J., Singh, B., Mullineux, G. and Medland, T. (2006), "Constraint-based approach to investigate the process flexibility of food processing equipment", Computers \& Industrial Engineering 51(4), pp. 809-820.

Melchels, F. P. W., Domingos, M. A. N., Klein, T. J., Malda, J., Bartolo, P. J. and Hutmacher, D. W. (2012), "Additive manufacturing of tissues and organs", Progress in Polymer Science 37(8), pp. 1079-1104.

Minetola, P., Iuliano, L., Bassoli, E. and Gatto, A. (2015), "Impact of additive manufacturing on engineering education - evidence from Italy", Rapid Prototyping Journal 21(5), pp. 535-555.

Mohamed, Z. M., Youssef, M. A. and Huq, F. (2001), "The impact of machine flexibility on the performance of flexible manufacturing systems", International Journal of Operations \& Production Management 21(5/6), pp. 707-742.

Naim, M., Aryee, G. and Potter, A. (2010), "Determining a logistics provider's flexibility capability", International Journal of Production Economics 127(1), pp. 39-45.

Naim, M. M., Childerhouse, P., Disney, S. M. and Towill, D. R. (2002), "A supply chain diagnostic methodology: determining the vector of change", Computers \& Industrial Engineering 43(1-2), pp. 135-157.

Naim, M. M., Potter, A. T., Mason, R. J. and Bateman, N. (2006), "The role of transport flexibility in logistics provision", International Journal of Logistics Management 17(3), pp. 297-311.

Nandkeolyar, U. and Christy, D. P. (1992), "An investigation of the effect of machine flexibility and number of part families on system performance", International Journal of Production Research 30(3), pp. 513-526.

Narasimhan, R. and Das, A. (1999), "An empirical investigation of the contribution of strategic sourcing to manufacturing flexibilities and performance", Decision Sciences 30(3), pp. 683-718.

Newman, W. R., Hanna, M. and Maffei, M. J. (1993), "Dealing with the uncertainties of manufacturing: Flexibility, buffers and integration", International Journal of Operations \& Production Management 13(1), pp. 19-34.

Obama, B. (2013), Remarks by the President in the State of the Union Address [Online]. Available at: http://www.whitehouse.gov/the-press-office/2013/02/12/remarks-president-state-union-address [Accessed: 9 December 2013]. 
Oke, A. (2005), "A framework for analysing manufacturing flexibilty", International Journal of Operations \& Production Management 25(10), pp. 973-996.

Onuh, S. O. and Hon, K. K. B. (2001), "Integration of rapid prototyping technology into FMS for agile manufacturing", Integrated Manufacturing Systems 12(3), pp. 179-186.

Overmeyer, L., Neumeister, A. and Kling, R. (2011), "Direct precision manufacturing of three-dimensional components using organically modified ceramics", CIRP Annals - Manufacturing Technology 60(1), pp. 267270 .

Parnaby, J. (1979), "Concept of a manufacturing system", International Journal of Production Research 17(2), pp. 123-135.

Parnaby, J. (1987), "Education and training in manufacturing systems engineering", IEE Proceedings 134 Part A(10), pp. 816-824.

Pérès, F. and Noyes, D. (2006), "Envisioning e-logistics developments: Making spare parts in situ and on demand: State of the art and guidelines for future developments", Computers in Industry 57(6), pp. 490-503.

Petkova, B. N. and van Wezel, W. eds. 2006. Disentangling manufacturing flexibility. 14th International Working Seminar on Production Economics. Innsbruck, 20-24 February 2006.

Pfleging, W., Bruns, M., Welle, A. and Wilson, S. (2007), "Laser-assisted modification of polystyrene surfaces for cell culture applications", Applied Surface Science 253(23), pp. 9177-9184.

Prabhu, V. V., Fuke, I. V., Cho, S. and Singh, J. (2005), "Rapid manufacturing of rhenium components using EB-PVD", Rapid Prototyping Journal 11(2), pp. 66-73.

Reinke, J. (2007), "Cashing In", Industrial Maintenance \& Plant Operation 68(5), pp. 8-10.

Rosen, D. W. (2004), "Additive manufacturing technologies: Opportunities for customization, flexibility, complexity, and simplicity", In: Shapira, P. et al. eds. Advanced technology and the future of U.S. manufacturing. Atlanta, GA. pp. 34-43.

Sawhney, R. (2006), "Interplay between uncertainty and flexibility across the value-chain: Towards a transformation model of manufacturing flexibility", Journal of Operations Management 24(5), pp. 476-493.

Schmidt, M., Pohle, D. and Rechtenwald, T. (2007), "Selective Laser Sintering of PEEK", CIRP Annals Manufacturing Technology 56(1), pp. 205-208.

Sethi, A. K. and Sethi, S. P. (1990), "Flexibility in manufacturing: a survey", International Journal of Flexible Manufacturing Systems 2(4), pp. 289-328.

Shewchuk, J. P. and Moodie, C. L. (1998), "Definition and classification of manufacturing flexibility types and measures", International Journal of Flexible Manufacturing Systems 10(4), pp. 325-349.

Slack, N. (1983), "Flexibility as a manufacturing objective", International Journal of Operations \& Production Management 3(3), pp. 4-13. 
Slack, N. (1987), "The flexibility of manufacturing systems.", International Journal of Operations \& Production Management 7(4), pp. 35-45.

Slack, N. (2005), "The changing nature of operations flexibility", International Journal of Operations \& Production Management 25(12), pp. 1201-1210.

Stevenson, M. and Spring, M. (2007), "Flexibility from a supply chain perspective: definitions and review", International Journal of Operations \& Production Management 27(7), pp. 685-713.

Stuart, I., McCutcheon, D., Handfield, R., McLachlin, R. and Samson, D. (2002), "Effective case research in operations management: a process perspective", Journal of Operations Management 20(5), pp. 419-433.

Tanrisever, F., Morrice, D. and Morton, D. (2012), "Managing capacity flexibility in make-to-order production environments", European Journal of Operational Research 216(2), pp. 334-345.

Thijs, L., Verhaeghe, F., Craeghs, T., Humbeeck, J. V. and Kruth, J.-P. (2010), "A study of the microstructural evolution during selective laser melting of Ti-6Al-4V", Acta Materialia 58(9), pp. 3303-3312.

Upton, D. M. (1994), "The management of manufacturing flexibility", California Management Review 36(2), pp. $72-89$.

Vokurka, R. J. and O'Leary-Kelly, S. W. (2000), "A review of empirical research on manufacturing flexibility", Journal of Operations Management 18(4), pp. 485-501.

Voss, C., Tsikriktsis, N. and Frohlich, M. (2002), "Case research in operations management", International Journal of Operations \& Production Management 22(2), pp. 195-219.

Wadhwa, R. S. (2012), "Flexibility in manufacturing automation: A living lab case study of Norwegian metalcasting SMEs", Journal of Manufacturing Systems 31(4), pp. 444-454.

West, A. P., Sambu, S. P. and Rosen, D. W. (2001), "A process planning method for improving build performance in stereolithography", Computer-Aided Design 33(1), pp. 65-79.

Wilden, J. and Fischer, G. (2007), "Laser synthesis of nanostructured ceramics from liquid precursors", Applied Surface Science 254(4), pp. 1067-1072.

Wong, M., Tsopanos, S., Sutcliffe, C. J. and Owen, I. (2007), "Selective laser melting of heat transfer devices", Rapid Prototyping Journal 13(5), pp. 291-297.

Xiong, J., Zhang, G., Qiu, Z. and Li, Y. (2013), "Vision-sensing and bead width control of a single-bead multilayer part: material and energy savings in GMAW-based rapid manufacturing", Journal of Cleaner Production 41, pp. $82-88$.

Yin, R. K. (2009), Case study research: Design and methods, 4th ed. Thousand Oaks, CA: SAGE Publications.

Zhang, B., Chen, J. and Coddet, C. (2013), "Microstructure and transformation behavior of in-situ shape memory alloys by Selective Laser Melting Ti-Ni mixed powder", Journal of Materials Science \& Technology 29(9), pp. 863-867. 


\section{Appendix: Case 2 - Model Medieval Ship (Design Component)}

Overview: Reverse engineering of over 700 medieval ship timbers to achieve 3D design models for subsequent 1:10 scaling, manipulation, and manufacture. Focal enabling resources: Four FaroARM coordinate measuring machines (A) each operated by a skilled technician (B), and a 3D CAD terminal (C) operated by a skilled archaeologist (D)

Evidence Sources for Design Component: Interviews with archaeologist $(\mathrm{n}=2)$ and observation by researcher at plant tours $(\mathrm{n}=2)$

\begin{tabular}{|c|c|c|c|}
\hline Internal & Focal & Flexibility Evaluation Summary & Flexibility \\
\hline
\end{tabular} Flexibility

Competency

Equipment
Flexibility Resource

\begin{tabular}{|l}
\hline $\mathrm{A}$ \\
\hline $\mathrm{B}$ \\
\hline $\mathrm{C}$ \\
\hline $\mathrm{D}$ \\
\hline $\mathrm{A}$
\end{tabular}

FaroARM control software was demonstrated as being easily moved between different operations by skilled operator as-needed without notable penalty.

\begin{tabular}{|c|c|c|c|}
\hline & & \\
\hline & D & & \\
\hline \multirow{4}{*}{$\begin{array}{l}\text { Process } \\
\text { Flexibility }\end{array}$} & A & $\begin{array}{l}\text { FaroARM machines were used to scan over } 700 \text { different timbers without configuration change. There is no setup operation needed between } \\
\text { timbers, and no identified penalty arising from the processing of different timbers. }\end{array}$ & \multirow{4}{*}{2} \\
\hline & $\mathrm{B}$ & Technician operating FaroARM shown to employ the same skills to each timber, with no penalty in moving between different timbers. & \\
\hline & $\mathrm{C}$ & 3D CAD terminal software shown to process all timbers without configuration change, with no penalty in moving between different timbers. & \\
\hline & $\mathrm{D}$ & $\begin{array}{l}\text { Skilled 3D CAD operator needs to manually optimize and fix each timber's design file, using CAD skills and archaeological expertise. This } \\
\text { process takes 2-3 hours per timber. Each timber needs to be carefully reviewed, and additional investigation may be needed in its optimization. This } \\
\text { leads to a small time penalty in moving between timbers. }\end{array}$ & \\
\hline \multirow{4}{*}{$\begin{array}{l}\text { Operation } \\
\text { Flexibility }\end{array}$} & A & \multirow{4}{*}{$\begin{array}{l}\text { Precedence operations largely dictated the sequence of operations (i.e. FaroARM scanning must be undertaken before 3D CAD operations can be } \\
\text { undertaken). Some evidence of sequences being altered for some of the initial timbers where prototyping was required, however this was shown to } \\
\text { disrupt overall production with considerable penalty. For this reason for the majority of operations were performed in predetermined sequence } \\
\text { where possible. }\end{array}$} & \multirow{4}{*}{3} \\
\hline & $\mathrm{B}$ & & \\
\hline & $\mathrm{C}$ & & \\
\hline & $\mathrm{D}$ & & \\
\hline \multirow{4}{*}{$\begin{array}{l}\text { Capacity } \\
\text { Flexibility }\end{array}$} & A & Four machines owned; no opportunity to increase or decrease these without permanent change. & \multirow{4}{*}{-} \\
\hline & $\mathrm{B}$ & $\begin{array}{l}\text { Skilled nature of work means that only experienced archaeological technicians are able to perform the work; very difficult to increase / decrease } \\
\text { without permanent change. }\end{array}$ & \\
\hline & $\mathrm{C}$ & One machine owned; no identified opportunity to increase or decrease these without permanent change. & \\
\hline & $\mathrm{D}$ & $\begin{array}{l}\text { Skilled nature of work means that only nautical archaeologist able to perform the work; very difficult to increase / decrease without permanent } \\
\text { change. }\end{array}$ & \\
\hline \multirow{3}{*}{$\begin{array}{l}\text { Routing } \\
\text { Flexibility }\end{array}$} & A & \multirow{2}{*}{$\begin{array}{l}\text { Ownership of } 4 \text { FaroARM tools and their associated process flexibility allows different timbers to take different routes through the scanning } \\
\text { process. Whilst this has no direct penalty on the system, in practice to control workflow exploitation of routing flexibility was not typically used. }\end{array}$} & \multirow{3}{*}{3} \\
\hline & $\mathrm{B}$ & & \\
\hline & $\begin{array}{l}\mathrm{C} \\
\mathrm{D}\end{array}$ & $\begin{array}{l}\text { Having only one 3D CAD terminal and skilled archaeologist inhibits routing flexibility of timbers. Additional routes only possible by achieving } \\
\text { capacity flexibility, which was very difficult due to the archaeological expertise required. }\end{array}$ & \\
\hline \multirow{4}{*}{$\begin{array}{l}\text { Program } \\
\text { Flexibility }\end{array}$} & A & \multirow{4}{*}{$\begin{array}{l}\text { All operations for FaroARM or 3D CAD require extensive involvement by skilled technicians, with no evidence found for unattended operation or } \\
\text { potential for it. }\end{array}$} & \\
\hline & B & & \\
\hline & $\mathrm{C}$ & & \\
\hline & $\mathrm{D}$ & & \\
\hline \multirow{3}{*}{$\begin{array}{l}\text { Material } \\
\text { Handling } \\
\text { Flexibility }\end{array}$} & A & Electronic files were produced by the FaroARM devices under the operation of a skilled operator, and these are transferred & \multirow{3}{*}{1} \\
\hline & $\mathrm{B}$ & manufacturing system. There is no observed penalty in transferring the design of one timber versus another. & \\
\hline & $\begin{array}{l}\mathrm{C} \\
\mathrm{D}\end{array}$ & $\begin{array}{l}\text { Electronic files were produced by the 3D CAD terminal under the operation of a skilled archaeologist, and these are transferred through the } \\
\text { manufacturing system. There is no observed penalty in transferring the design of one timber versus another. }\end{array}$ & \\
\hline
\end{tabular}





\begin{tabular}{|c|c|c|c|c|c|c|}
\hline Activity & $\begin{array}{l}\text { Identification of study } \\
\text { context \& research aim }\end{array}$ & $\begin{array}{c}\text { Additive Manufacturing } \\
\text { flexibility review \& } \\
\text { initial theoretical } \\
\text { development }\end{array}$ & $\begin{array}{l}\text { Operationalization of } \\
\text { flexibility typology } \\
\text { method }\end{array}$ & $\begin{array}{c}\text { Internal flexibility } \\
\text { competences assessment }\end{array}$ & $\begin{array}{c}\text { External flexibility } \\
\text { capabilities assessment }\end{array}$ & $\begin{array}{c}\text { Contextualizing findings } \\
\text { to existing body of } \\
\text { knowledge }\end{array}$ \\
\hline $\begin{array}{l}\text { Nature of } \\
\text { research }\end{array}$ & Observational & Theoretical & Theoretical \& empirical & Empirical & Empirical & Empirical \& theoretical \\
\hline Outcomes & $\begin{array}{l}\text { Initial insights from } \\
\text { theory \& practical } \\
\text { observations identified }\end{array}$ & $\begin{array}{c}\text { Research gaps } \\
\text { confirmed. Research } \\
\text { questions \& flexibility } \\
\text { typology formulated }\end{array}$ & $\begin{array}{l}\text { Flexibility assessment } \\
\text { schema \& procedure } \\
\text { employed for twelve } \\
\text { case studies }\end{array}$ & $\begin{array}{l}\text { Detailed assessment of } \\
\text { internal flexibility } \\
\text { competences for twelve } \\
\text { case studies }\end{array}$ & $\begin{array}{l}\text { Identification of external } \\
\text { capability enablement } \\
\text { and derivation of } \\
\text { emergent capabilities }\end{array}$ & $\begin{array}{l}\text { Research questions } \\
\text { answered, limitations } \\
\text { explained, and future } \\
\text { research suggested }\end{array}$ \\
\hline $\begin{array}{c}\text { Modus } \\
\text { operandi }\end{array}$ & $\begin{array}{l}\text { Literature-based with } \\
\text { reference to practice }\end{array}$ & Literature-based & $\begin{array}{l}\text { Qualitative: Interviews, } \\
\text { observations, company } \\
\text { documents }\end{array}$ & $\begin{array}{c}\text { Team-based } \\
\text { interpretation \& analysis } \\
\text { of data }\end{array}$ & $\begin{array}{c}\text { Team-based } \\
\text { interpretation \& analysis } \\
\text { of data }\end{array}$ & Reflective appraisal \\
\hline Focus in & Section 1 & Section 2 & Section 3 & Section 4 & Section 5 & Section 6 \\
\hline
\end{tabular}

